\title{
Occurrence, sources, human health impacts and mitigation of microplastic pollution
}

Samaneh Karbalaei ${ }^{1^{*}}$, Parichehr Hanachi ${ }^{1}$, Tony R. Walker ${ }^{2}$, Matthew Cole ${ }^{3}$

${ }^{1}$ Department of Biology, Biochemistry Unit, Alzahra University, Tehran, Iran

${ }^{2}$ School for Resource and Environmental Studies, Dalhousie University, Halifax, NS, B3H 4R2, Canada

${ }^{3}$ Plymouth Marine Laboratory, Plymouth, United Kingdom

* Corresponding author: Samaneh Karbalaei

Department of Biology, Biochemistry Unit, Alzahra University, Tehran, Iran

Phone: +989125457850

e-mail: samaneh.karbalaei@gmail.com 


\begin{abstract}
The presence and accumulation of plastic and microplastic (MP) debris in the natural environment is of increasing concern and has become the focus of attention for many researchers. Plastic debris is a prolific, long-lived pollutant, that is highly resistant to environmental degradation, readily adheres hydrophobic persistent organic pollutants and is linked to morbidity and mortality in numerous aquatic organisms. The prevalence of MPs within the natural environment are a symptom of continuous and rapid growth in synthetic plastic production and mismanagement of plastic waste. Many terrestrial and marine-based processes, including domestic and industrial drainage, maritime activities agricultural runoff and wastewater treatment plants (WWTPs) effluent, contribute to MP pollution in aquatic environments. MPs have been identified in food consumed by human and in air samples, and exposure to MPs via ingestion or inhalation could lead to adverse human health effects. Regulations in many countries have already been established or will soon be implemented to reduce MPs in aquatic environments. This review focuses on the occurrence, sources, and transport of MPs in terrestrial and aquatic environments to highlight potential human health effects, and applicable regulations to mitigate impacts of MPs. This study also highlights the importance of personality traits and cognitive ability in reducing the entry of MPs into the environment.
\end{abstract}

Keywords: Microplastics; Microfibres, Marine, Freshwater and terrestrial microplastics; Controlling sources of microplastics. 


\section{Introduction}

Since development of the first synthetic resin at the beginning of the 20th century, plastics have become indispensable in society (Cole et al. 2011; Sivan 2011). Plastics or synthetic organic polymers are derived from natural, organic materials such as coal, natural gas, and crude oil by polymerisation or polycondensation processes (Phuong et al. 2016). There has been a significant increase in global production of plastics in the last fifty years, with production rising from 1.7 million tonnes in the 1950 s to 335 million tonnes in 2016 (PlasticsEurope 2017). It is estimated that 8 million metric tons $(\mathrm{Mt})$ of generated plastic waste on land entered the marine environment in 2010 alone (Geyer et al. 2017; Jambeck et al. 2015). Trends of global plastic production, consumer-use patterns, inappropriate disposal of plastic waste and demographics suggest an increase of plastic use in the future. Plastic demand is growing exponentially, and trends of production are expected to quadruple by 2050 (Suaria et al. 2016). Although industrial benefits of plastic are widespread, this valuable commodity has become a considerable environmental concern for governmental and private sectors, scientists, and general public (Seltenrich 2015). Key concerns include: (a) plastic is a non renewable resource; (b) persistent organic pollutants (POPs) are sorbed very efficiently to plastics; (c) durability of plastic makes it highly resistant to degradation; (d) plastic debris is vulnerable to fragmentation; (e) plastic debris can cause injury and death of marine birds, mammals, fish and reptiles towing to plastic entanglement and ingestion (Lopez Lozano and Mouat 2009; Trevail et al. 2015; Van Franeker et al. 2011; Wright et al. 2013); and (f) plastic debris can damage maritime equipment (Phuong et al. 2016). Furthermore, the presence of macroplastic debris (larger than $5 \mathrm{~mm}$; Driedger et al. 2015) can create aesthetic issues, damage to the seabed because of sinking plastic debris, and economic pressures on the shipping sector (fouled motors, lost output and repair costs), fishing (lost or discarded nets), and tourism by loss of revenues (Cole et al. 2011). For example, in 2011 vast amounts of marine debris on the beaches of Geoje Island, South Korea affected the island's tourism industry, with lost revenue estimated at US \$29 - 37 million (Jang et al. 2014).

The term microplastics (MPs), first coined in the scientific literature by Thompson et al. (2004), describes very small plastic particulates and fibres. The size definitions for MPs are non-uniform, and include: $>1.6 \mu \mathrm{m}(\mathrm{Ng}$ and Obbard, 2006), <1 mm (Browne et al. 2007, 2010; Claessens et al. 2011), <2 mm (Ryan et al. 2009), 2-6 mm (Derraik 2002), <5 mm (Barnes et al. 2009; Betts 2008), <10 mm (Graham and Thompson 2009). The National Oceanic and Atmospheric Administration (NOAA) now defines the term MPs as tiny ubiquitous plastic particles <5 $\mathrm{mm}$ in diameter (Arthur et al. 2009). Origins of MPs can be distinguished as primary and secondary sources (Cole et 
al. 2011). Primary MPs (microbeads) are defined as plastics produced at a micro-sized scale, including those generated for use in industrial and domestic products such as hand and facial cleansers to strengthen cleansing or exfoliating functions (Zitko and Hanlon 1991), cosmetics, medicine as drug vectors (Patel et al. 2009) and scrubbers in air-blasting (Gregory 1996). Lei et al. (2017) reported the presence of different shapes and contents of MPs, mainly polyethylene (PE) in various facial cleansers and shower gels in Beijing, China. Secondary MPs result from the breakdown of macroplastics items both at sea and on land (Ryan et al. 2009; Thompson et al. 2004); plastics undergo different degradation processes in the environment, including mechanical (erosion, wave action, abrasion), chemical (photooxidation, temperature, corrosion) and biodegradation activities, which lead to their fragmentation into MP (Andrady 2011; Zettler et al. 2013). It is believed that the fragmentation of plastic debris in coastal environment is much faster than in water because plastic degrades mainly via solar UV-radiation-induced oxidation and the rate of degradation can be accelerated by the high temperature and UV radiation on the coast surface in comparison to the sea surface (Andrady 2015). Also, chemical and mechanical breakdown of plastic debris is increased during saltation in coastal environments (Corcoran et al. 2009).

MPs are generated mainly from land-based sources ( $80 \%)$, and also from sea-based sources ( 20\%) (Barboza et al. 2019), and are able to move great distances throughout the world because of their properties such as lightweight, durability, buoyancy, shape, and colour (Fig. 1). MPs are also widespread in the terrestrial environments as a consequence of daily human activities. Terrestrial ecosystems are considered as major sources and transport pathways of MPs into the marine environment (Horton et al. 2017b). MPs are dispersed into the ocean all over the world. Often detected in beaches (Herrera et al. 2017; Imhof et al. 2018; Naji et al. 2017), seabed sediments (Karlsson et al. 2017; Van Cauwenberghe et al. 2013), wastewater effluents (Magnusson and Norén 2014; Murphy et al. 2016; Ziajahromi et al. 2016), surface waters (Eriksen et al. 2013; La Daana et al. 2017), freshwater systems (Horton et al. 2017b) and even sea ice in the Arctic (Lusher et al. 2015; Obbard et al. 2014; Waller et al. 2017), and the Antarctic (Waller et al. 2017) transported by ocean and wind. MPs also have been observed in the atmosphere, as well as in indoor and outdoor environments (Dris et al. 2017; Gasperi et al. 2018). Bergmann et al. (2017) found high concentrations of MPs (including fibers) in Arctic sea ice, potentially originating from the atmosphere.

$<$ Fig. 1 $>$

A potential environmental risk associated with MPs is their bioavailability throughout the food-web (Cole et al. 2011; Kolandhasamy et al. 2018). Due to the large presence of MPs in aquatic and terrestrial environments, they 
would be present in food products that sold for human consumption. Identifying original sources and distribution of MPs in terrestrial and aquatic environments will help to identify potential mitigation options to decrease transport of MPs into the environment. This review focuses on the occurrence, sources, and transport of MPs in terrestrial and aquatic environments to highlight potential human health effects, and applicable regulations to mitigate impacts of MP pollution.

\section{Occurrence and pollution of MPs in terrestrial and aquatic ecosystems}

\subsection{MPs in terrestrial ecosystems}

A wide range of MPs are found in terrestrial ecosystems owing to a plethora of anthropogenic activities, yet only a limited number of studies have explored the abundance of MPs on land; typically, current studies consider terrestrial ecosystems only as sources and distribution pathways of MPs to aquatic or marine environments (Horton et al. 2017b; Jambeck et al. 2015; Lechner et al. 2014; Rillig 2012). Lechner et al. (2014) showed the release of substantial amounts of industrial MPs from a production plant into the River Danube, which is legally discharged into the river (Lechner et al. 2014). Soils are essential components of terrestrial ecosystems that can experience heavy anthropogenic pollution pressure (Walker et al. 2003). Fragmentation of plastics at coastal areas or in surface water occurs as a consequence of direct exposure to UV-radiation from sunlight and physical abrasion processes; however, both drivers are mostly missing in soil, therefore fragmentation of plastic in soil could be very slow. Some studies reported minimal degradation of synthetic polymers in soil. Albertsson (1980) detected only 0.1 to $0.4 \%$ weight loss of PE in soil after 800 days. Another study by Arkatkar et al. (2009) reported only $0.4 \%$ weight loss of polypropylene (PP) in soil after one-year incubation, while no degradation of polyvinyl chloride (PVC) was found in soil after 10 to 35 years (Ali et al. 2014; Otake et al. 1995; Santana et al. 2012). Soil texture is also a key factor that affects the rate of polymer degradation. César et al. (2009) found that degradation was enhanced in clay soils when compared with sandy soils. De Souza Machado et al. (2018) showed the potential of MPs to disturb vital relationships between soil and water due to the effect of MPs on bulk density, and water holding capacity, as well as its consequences for soil structure and microbial activity. Studies on the existence of MPs in soil are scarce because of the quantification of MPs in soil is a challenge and analytical techniques required for this type of analysis is still relatively new. Thus, the identification of MPs in soils needs to be developed before assessing the MPs content of different soils. There are three promising methods for characterising MPs in soils published recently; however, they have still limitations in their method. For instance, Fuller and Gautam (2016) developed a method based on 
pressurized fluid extraction (PFE) for measuring MPs in soil samples, but the limitation is inability of the method to measure size fractions of MPs. PFE is a standard extraction technique that uses solvents at subcritical temperature and pressure conditions, and is commonly applied in environmental laboratories for the extraction of organic pollutants from soils, sediments and wastes. Using this method they found that topsoils near industrial areas around Sydney (Australia) contain $0.03 \%$ to $6.7 \%$ of MPs. Shan et al. (2018) showed that hyperspectral imaging technology is a novel way to measure and visualize the MPs with particle size from 0.5 to $5 \mathrm{~mm}$ on soil surface directly. Another study conducted by Zhang et al. (2018) introduced a simple and cost-saving method (floatation and heating method) to extract, distinguish and quantify light density MPs (e.g., PE and PP) in soil. In a floatation method, distilled water was used to extract the MPs from soil samples with recovery rates of approximately $90 \%$. Then, samples were exposed to heat and MPs in the soil samples melted and transformed into circular transparent particles. This method is limited to measure light density plastics. On the contrary, Scheurer and Bigalke (2018) developed a promising alternative method to analyse size distribution, composition, and concentrations of most commonly produced MPs in soils by FT-IR microscopy.

Many factors affect the amount of deposition, retention and transport of MPs including human behaviours (e.g., general littering, dumping of plastic waste, inappropriate waste management), characteristics of particles (e.g., density, shape, and size), weather conditions (e.g., wind, rainfall), and environmental topography (Zylstra 2013). A considerable direct input of primary MPs to terrestrial ecosystems and soils have been identified as being through areal deposition, sedimented MPs from personal care products or household items, landfills or other surface deposits, and sludge application to agricultural land (Horton et al. 2017b; Rillig 2012; Steinmetz et al. 2016). Typically, in industrialised countries, landfills are surrounded by fences, and waste is usually covered with soil or a synthetic material, which helps mitigate MP run-off from such sites. However, in developing countries, these best management practices are often not followed (Duis and Coors 2016). There is a significant plastic waste accumulation in soils in many tropical and subtropical countries, also agricultural/municipal plastic wastes are buried or disposed in open fields, gardens, or landfills. In Europe, around 1000 to more than 4000 MPs particles/kg of dry mass sludge were found in agricultural and landfill sites (Huerta Lwanga et al. 2016). In another study by Fuller and Gautam (2016), the presence of MPs were observed in various soils from an industrial area in Australia. It is estimated that up to 700,000 tons of MPs may enter farmland annually through biosolids application in Europe and North America (Nizzetto et al. 2016). 
MPs from personal care products (e.g., shower gels, hand cleaners, shampoos, facial cleaners and toothpaste) can reach the environment through wastewater treatment plants (Duis and Coors 2016). Industrial abrasives such as polystyrene (PS), polyester (PES), melamine can end up in the environment, if not used properly in closed systems. Other sources of primary MPs including plastic resin pellets/flakes and plastic powder/fluff can reach the environment after improper handling (Duis and Coors 2016). Similarly, residues from plastic processing and plastic recycling plants can end up in the environment (Andrady 2011; Duis and Coors 2016). The presence of high concentrations of raw materials used for the manufacture of plastic supplies were often observed on beaches nearby to plastic producing/processing sites (Duis and Coors 2016).

Some organisms including earthworms could contribute in formation of secondary MPs by grind up brittle plastic debris in their gizzard (Rillig 2012). Collembola or mites may also contribute to breakdown of plastics by scraping or chewing off pieces of plastic. Similarly, digging mammals could contribute to abrasion and incorporation of plastics into the soil (Rillig 2012). MPs could sorb chemical contaminants from the soil and concentrate them in the soil. Additionally, MPs could alter physical properties of the soil. Rillig et al. (2017) showed the downward movement of PS MPs from the soil surface to the soil profile via earthworms. According to the study by Rillig et al. (2017), there are several possible implications to carry MPs down the soil profile via available organisms: (a) Decomposition of organic material in the deep part of the soil is generally much slower due to few populations of microbes. It would mean that MPs may have longer durability in greater depths in the soil profile; (b) MPs after passing through the soil profile could potentially reach groundwater and lead to adverse effects on in other aquatic environments; (c) MPs may convert to nano-sized material due to further fragmentation in the soil, which poses different environmental risks.

However, some sewage treatment plants are effective at removing the majority of MPs (up to $99.9 \%$ removal of MP debris) from wastewater, but a significant number of MP debris will be retained within the sludge (Gies et al. 2018; Mintenig et al. 2017; Prata 2018a). In Portugal, more than $87 \%$ of the total amount of sewage sludge is applied as agricultural fertiliser (using biosolids) either directly or after composting (Alvarenga et al. 2016). Additionally, in the European Union (EU), between 4 and 5 million tonnes of sewage sludge (dry weight) are used to agricultural land every year. Zubris and Richards (2005) showed soils that received sludge products had significantly higher concentrations of synthetic fiber compared to field site soil which had not received sludge products. In some land sites, synthetic fibres were found after 5 years sludge application. 


\subsection{Sources and transport of MPs into aquatic environments}

In the early 1970s, the first reports of plastics litter in the marine environment drew the minimal focus of the scientific society (Carpenter and Smith 1972; Colton et al. 1974). In recent decades, direct or indirect indiscriminate disposal of waste items to the marine environment and associated ecological impacts of debris has increased sustained research interest (Walker et al. 1997). Early studies focused on the entanglement of marine fauna such as whales (France 2016), fur seals (Boren et al. 2006), turtles (Mascarenhas et al. 2004), seabirds (O'Hanlon et al. 2017), and cetaceans (Baulch and Perry 2014) in net fragment litter or via 'ghost fishing'. More recently, studies showing ingestion of MPs by marine biota including fish, mussels, shrimps, have become extensively documented (Catarino et al. 2018; Devriese et al. 2015; Neves et al. 2015; Rummel et al. 2016). Further, toxicological studies of MPs and chemical co-transport on marine organisms are assessed for these multifaceted stresses (Akhbarizadeh et al. 2018; Batel et al. 2016). MPs are transported and dispersed throughout the oceans, including beaches, in deep-sea and coastal sediments, and on surface waters from the Arctic to the Antarctic from remote locations (Barnes et al. 2010; International Maritime Organization 2015). Recently, a predominant abundance of PE and PP MPs were found in subsurface waters in the coastal area of the Ross Sea (Antarctica) (Cincinelli et al. 2017). Plastic particles also detected in sediments collected in Terra Nova Bay (Ross Sea, Antarctica), which fibres were the most frequent type of plastics debris found (Munari et al. 2017). Waller et al. (2017) reviewed several sources of MPs within the Southern Ocean: (a) MPs are discharged from wastewater in scientific research stations (52\% of research stations had no wastewater treatment systems); (b) fishing and tourist ships; (c) MPs may release into the Southern Ocean from personal care products and laundering synthetic fabrics because of human presence in the region, scientific research stations, and vessels; (d) MPs from degradation of floating debris pollution originating in the Southern Ocean due to high UV levels; (e) Plastics originating outside the Southern Ocean due to major current systems of the Southern Ocean. Another study by Bergmann et al. (2017) showed high quantities of MPs including chlorinated PE (38\%), polyamide (PA) (22\%) and PP (16\%) in Arctic deep-sea sediments from the HAUSGARTEN observatory. In 2016, a field survey was conducted to collect MPs with sizes $<5 \mathrm{~mm}$ in the Southern Ocean. Of the 44 fragments found in this study, 29 were made of PE, PP, and PE combined with unidentified polymers. However, 14 of the remaining 15 MPs were made of PS, and 1 was made of PVC (Isobe et al. 2017). High level of MPs was also observed in Arctic seabird, the northern fulmar (Fulmarus glacialis), which highlight the risk to seabirds and other 
sea ice animals from plastic pollution (Trevail et al. 2015). Similarly, a recent study by Avery-Gomm et al. (2018) also showed plastic ingested by $F$. glacialis (with an average of $0.151 \mathrm{~g} / \mathrm{bird}$ ) from the southeastern Canadian waters of the Labrador Sea. Also, Provencher et al. (2018) found MPs in 47\% of the faecal precursor from F. glacialis, which suggest that seabirds are acting as vectors of MPs in the marine environment through guano deposition near their colonies.

It is generally considered that $75-90 \%$ of marine plastic originates from land-based and the rest (about 10-25\%) originates from ocean-based sources (Andrady 2011; Duis and Coors 2016; Walker et al. 2006). The MPs debris present in cosmetics such as scrubbers in cleaning products, exfoliating creams, air blasting media, and fibres from laundry can enter the aquatic environment through industrial and domestic drainage systems. Wastewater treatment plants (WWTPs) are one of the dominant point sources of MPs to the marine environment (Magnusson and Norén 2014; Mintenig et al. 2017; Murphy et al. 2016). High concentrations of MPs release every day at WWTPs (Prata 2018a). Recent cases reported by Cesa et al. (2017) also showed synthetic fibers from textile produce MPs sheds which originated from domestic washing and WWTPs. Although, WWTPs have an up to 95\% removal of MPs (Prata 2018a; Talvitie and Heinonen 2014; Talvitie et al. 2017) and tertiary treatment can remove a 90\% of debris in a size larger than $10 \mu \mathrm{m}$ (Wardrop et al. 2016), however, there is a significant amount of MPs being discharged into aquatic environment through WWTPs. Gies et al. (2018) estimated that 1.76 (0.3) trillion MPs were discharged from a WWTP annually in Vancouver, Canada, of which $1.28(0.54)$ trillion MPs settled into primary sludge, $0.36(0.22)$ into secondary sludge, and 0.03 (0.01) trillion MPs were released into the marine receiving environment. Thus, this corresponds to a retention of MPs of up to $99 \%$ in this WWTP. A recent study by Mason et al. (2016) studied the effluent samples of 17 WWTPs across the United States (US) and predicted that the average discharge of MPs particles was 13 billion pieces/day. In Finland, an annual estimate of 154,000 to 411,000 kg of PES and cotton microfibers are released in washing machines (Sillanpää and Sainio 2017). Browne et al. (2011) compared MPs found in shoreline sediment samples with MPs detected from samples of marine wastewater effluent disposal site and showed mostly PES and acrylic fibres in both sample types. Further, a study by Talvitie et al. (2015) suggested that wastewater effluents act as a transport pathway for MPs to be released in the environment as they found similar types of MPs (mostly fibres and synthetic particles) in both effluent from a WWTP in Finland and seawater from the Gulf of Finland. 
MPs get into the aqueous environment through storm sewers runoff, wind advection and currents (Murphy et al. 2016; Zalasiewicz et al. 2016). Additionally, storm drains from roads may also transport plastic debris such as fragments of road-marking paints (Horton et al. 2017a) and tyre wear particles into natural water (Galgani et al. 2015). Another direct source of MPs to terrestrial and marine environments is fragmentation of plastics that are used in agricultural lands. For example, plastic mulches are used to increases yields, fruit quality, water-use efficiency, control temperature and moisture in agricultural and horticultural applications, however, MPs are the potential pollution by plastic mulches (Steinmetz et al. 2016). Additional products applied in agriculture are silage and fumigation films, anti-bird, fertiliser sacks, and containers, all of which have the potential for dispersion of MPs within the environment (Muise et al. 2016; Scarascia-Mugnozza et al. 2012). Large amounts of plastic debris can also enter the marine environment during natural disasters such as hurricanes, tsunamis and strong sea (Desforges et al. 2014).

Anthropogenic activities along the coast enter significant amount of MPs to the marine environment such as harbours, recreational, shipping and fishing activities (Driedger et al. 2015). For example, material lost or discarded from fishing ship, aquaculture facilities, and merchant ships are the sources of marine litter. Many ship paints contain synthetic polymers such as polyacrylate, PS, alkyds, and epoxy resins, which is in direct contacts with water (Sundt et al. 2014). MPs were also found in seven intertidal mangroves habitats of Singapore due to the degradation of marine plastic debris (Mohamed Nor and Obbard 2014).

To date, ingestion has been widely accepted as the common pathway for a wide range of aquatic organisms to uptake MPs (Ferreira et al. 2016; Rochman et al. 2013). Bivalves (Mathalon and Hill 2014; Li et al. 2015), zooplankton (Cole et al. 2013), fishes (Rummel et al. 2016), shrimps (Devriese et al. 2015), oysters (Green 2016), sea cucumbers (Graham and Thompson 2009), polychaete worms (Wright et al. 2013), and whales (Fossi et al. 2012) have been reported to ingest MPs. Ingestions of MPs by marine animals lead to adverse health effects including decreased food consumption, false satiation, decreased growth rate, reproductive complications, behavior, oxidative stress, decreased immune response, weight loss, pathological stress, blocked enzyme production could potentially threat marine populations and living resources (Fossi et al. 2016; GESAMP 2016; Lusher et al. 2017; Rochman et al. 2015; Sutton et al. 2016).

Despite the large and growing literature regarding the abundance, sources, and impacts of MPs in the marine environment (Galgani et al. 2015; Sundt et al. 2014; Waller et al. 2017), little information exists on MPs in 
freshwater aquatic ecosystems. Freshwater and terrestrial ecosystems are recognized as a main source and transport pathways of plastics to the marine environments (Su et al. 2018). A handful of recent studies have examined MPs in lakes (Driedger et al. 2015; Eriksen et al. 2013; Free et al. 2014; Imhof et al. 2018), lakeshore (Imhof et al. 2013; Zhang et al. 2016) sediments, pelagic MPs in rivers (Dubaish and Liebezeit 2013) and the ingestion of MPs by freshwater fauna (Pazos et al. 2017; Sanchez et al. 2014). Eriksen et al. (2013) show that plastic microbeads, which commonly used in facial cleansers and other personal care products, are a significant MPs pollutant in the Great Lakes. In the study conducted by Su et al. (2018), the level of industrialisation and hydrological conditions were proposed as important contributors to MPs pollution in Taihu Lake, China. High concentration of MPs across the Rhine River, one of the largest European rivers, reflecting various sources and sinks of MPs to the river such as wastewater treatment plants, effluents of industries, tributaries, and weirs, also highlights the important contribution of this river to the MPs mass in the North Sea (Mani et al. 2015).

Because of differences between freshwater and marine ecosystems including the close vicinity of point sources in freshwaters, proximity to urban centers, the smaller size of freshwater ecosystems, human population density proximal to the freshwaters, and differences in the spatial and temporal conditions in the mixing/transport of particles by physical forces, may lead to differences in the type and quantity of MPs present in freshwaters compared to marine systems (Eerkes-Medrano et al. 2015). Eriksen et al. (2013) found a major fraction of MPs in the surface waters of Lakes Superior, Huron, and Erie are most likely microbeads that are used in consumer products, such as exfoliating creams, soaps, shampoos, toothpastes, sunscreens, and deodorants. Also, Pelagic MPs in the highly populated Great Lakes of North America were significantly higher than particle counts for the less populated Lakes (Eriksen et al. 2013). The Rochman laboratory is currently studying the fate and transport of MPs in the Great Lakes and is also investigating rates of plastic microfibers shedding from textiles during washing cycles and their accumulation in aquatic environments. Additionally, there are ongoing studies in this laboratory (https://rochmanlab.com) on the transfer of chemical contaminants (e.g., PCBs and PAHs) and metals from plastic debris.

\subsection{Sources and dispersion of airborne MPs}

Vast data exist in the literature on the presence of MPs in the marine environment (Andrady 2011; Auta et al. 2017; Cesa et al. 2017; Cole et al. 2011; Wang et al. 2016; Wright et al. 2013), whereas there is a gap of knowledge on MPs in the air (Dris et al. 2017; Gasperi et al. 2018). The most important sources of airborne MPs are determined to 
originate from synthetic textiles, erosion and abrasion of synthetic rubber tires, city and household dust (Prata 2018b). A single item of clothing may be responsible for the discharge of around 1900 fibers per wash (Browne et al. 2011). Other sources of airborne MPs may include construction materials, waste incineration, landfilling (Dris et al. 2016), industrial outflows, roadway particles, resuspension of particles (Dris et al. 2015), synthetic particles such as PS peat, which applied in horticultural soils, use of sewage sludge in agriculture as a fertiliser, and tumble dryer exhaust (Prata 2018b). Dris et al. (2016) investigated the presence of fibrous MPs in the total atmospheric fallout at an urban site and suburban site in the Paris Megacity. Chemical characterization appeared that $29 \%$ of the fibers measured in total atmospheric fallout are synthetic (e.g., made with petrochemicals), or a composition of natural and synthetic materials.

Factors affecting MPs behavior and transport in the atmosphere may also be similar to those of fine particulate matter including vertical pollution concentration gradient (higher concentrations close to the land), wind speed (increasing of wind speed lead to a decrease in concentration), wind direction (downwind, upwind, and parallel directions), precipitation, temperature, and humidity (Kaur et al. 2007; Zhao et al. 2014). Also, urban topography (e.g., tall buildings, trees, and space between buildings) can affect wind modulation and distribution of air pollutants in urban environments (Fernando et al. 2001). Lighter polymers can be transported easily by the wind and further contaminate the terrestrial and marine environments (Horton et al. 2017b).

Indoor air is another important source and the main place of exposure to airborne MPs due to lower removal by dispersal mechanisms (Prata 2018b) and people spend around 70-90\% of their time inside (Alzona et al. 1979). The behavior of indoor airborne MPs depends on room partition, ventilation, and airflow (Alzona et al. 1979). Catarino et al. (2018) compared the potential exposure of humans to household dust fibres and MPs in caged mussels (Mytilus edulis). The result showed the risk of plastic ingestion through consumption of mussel is minimal compared to fibre exposure during a meal through household dust fallout. The MPs from the indoor air could contaminate the outside air, because they are diluted in the atmosphere (Dris et al. 2017), while only $30 \%$ of outdoor particulate matter can enter indoors in a closed room (Alzona et al. 1979). Fibres are the most common microplastic type observed in sediments (Claessens et al. 2011), surface seawaters (Lusher et al. 2014), aquatic biota (Rochman et al. 2015) as well as atmospheric fallout (Dris et al. 2016) and in indoor environments (Dris et al. 2017).

\section{MPs and potential human health impacts}


As an emerging area of concern to MPs is that they can also enter the human food chain through ingestion of seafood and terrestrial food products causing potential human health impacts (Rist et al. 2018; Wright and Kelly 2017) (see Table 1). The presence of MPs in the guts and tissues of aquatic species including some commercially important bivalves (Mathalon and Hill 2014; Li et al. 2015; Naji et al. 2018), crustaceans (Bos et al. 2018), and fish (Bessa et al. 2018a, 2018b; Neves et al. 2015) is well documented. Key factors contributing to the bioavailability of MPs are size, density, abundance, and colour (Wright et al. 2013). The small size of MPs makes them available to the lower trophic organisms, which can capture anything of appropriate size. The density of the MPs will determine bioavailability in the water column; therefore, the type of plastic debris ingested may vary between organisms. An increase in the abundance of MPs in the marine environment will also affect its bioavailability because the chance of organisms to encounter MPs is enhanced (Wright et al. 2013). In a study by Moore et al. (1998), the uptake of latex spheres $(1 \mu \mathrm{m})$ from the water in rainbow trout (Oncorhynchus mykiss) were observed in the surface and subsurface epidermal cells and underlying phagocytes of the skin and gill surface. This highlights the importance of epithelial cells in the adherence and entry of MPs to the fish body. Thus, consumption of the skin or gill tissue could also be a direct route of human exposure to MPs even $\geq 1 \mu \mathrm{m}$. In a study recently performed on the soft tissue of mussels strongly suggested that adherence is a novel way for organisms to accumulate MPs beyond ingestion (Kolandhasamy et al. 2018).

In addition to seafood, MPs have been reported in other food products, such as sea salt. The presence of MPs in sea salt has recently been reported through studies by Iñiguez et al. (2017), Karami et al. (2017a), and Yang et al. (2015). Karami et al. (2017a) investigated concentration of MPs from 17 brands of salt originating from 8 different countries and the number of MPs in salt was nil, in the range 0-10 MPs $/ \mathrm{kg}$. On the contrary, the amounts of MPs found in different Chinese and Spanish table salt were in the range of 7-680 MPs/kg and 50-280 MPs/kg, respectively (Iñiguez et al. 2017; Yang et al. 2015). Differences between the studies may be related to the errors in the experimental procedures used to extract the MPs. Therefore, further studies are required to improve the reliable method for quantifying MPs in salt. Additionally, both honey and sugar have been found to contain a small number of fibers and fragments (Liebezeit and Liebezeit 2013). An average of 174 (kg/honey) fibers and 9 (kg/honey) fragments, and an average of $217(\mathrm{~kg} / \mathrm{sugar})$ fibers and $32(\mathrm{~kg} / \mathrm{sugar})$ fragments were found. Authors suggested that the sources of synthetic MPs to contamination of honey are airborne. In contrast, a similar study on honey samples did not find a notable contamination of MPs (Mühlschlegel et al. 2017). Previous research has indicated that the 
methodology used in the studies on honey, sugar and beer (Liebezeit and Liebezeit 2013, 2014) was questioned due to the background contamination and wrong identification of plastic particles (Lachenmeier et al. 2015). Recently, MPs have been found in tap water (Kosuth et al. 2017) and bottled water (Schymanski et al. 2018). MP contamination were investigated in tap water from six regions on five continents. Plastic particles were found in $83 \%$ of analyzed samples (the range was between 0 and 57 particles/L) (Kosuth et al. 2017). However, the results lack a thorough analysis in the confirmation of synthetic origin of the particles. On the contrary, in the study on bottled water, a precise analysis was conducted, and the average MPs content was 118 particles/L in returnable and 14 particles/L in single-use plastic bottles that suggested found particles correlated with the materials the bottles were made of (Schymanski et al. 2018). There are thus still many uncertainties in methodology and analysis of MPs which should be improved by further researches.

A recent study by Karami et al. (2018) examined the potential presence of micro- and mesoplastics in canned sardines and sprats. Results showed the MPs were absent in 16 brands from 20 analyzed brands of canned sardines and sprats, and between 1 and 3 plastic particles per brand were found in the rest. The authors suggested that food safety management systems are urged to place test of MPs in their guidelines because of the possible increase in loads of MPs in canned fish.

Table 1 lists examples of studies on the presence of MPs in products consumed by humans which have mostly been conducted since 2016, because several jurisdictions such as the UK, US and Canada have passed legislation to bans MPs (specifically microbeads) at or around that time (Schnurr et al. 2018; Xanthos and Walker 2017). The consumption of MPs contaminated foods is a potential source of human MPs intake. Recent studies showed the most commonly plastic polymers found in food products are polyethylene-terephthalate (PET), PP, PE, PES, PVC, PS, PA, and nylon (Table 1). Plastic particles can impact on human health, with effects mainly related to toxicity of the chemical that absorbs from the environment or additives that are used in plastic materials. Non enzymes are reported to be available to degrade the synthetic polymers in any organism (Wang et al. 2016). Based on the UN Globally Harmonised System, more than 50\% of plastics are accompanied with hazardous monomers, additives, and chemical by-products (Lithner et al. 2011). PET is commonly used in the production of drink bottles, plastic film, microwavable packaging, pipes, and insulation molding, which is considered as a potential human carcinogen (Li et al. 2016). PS is also commonly used in the production of Packaging foam, disposable cups, plates, tableware, CD, tanks, and building materials (insulation). PS and PVC have been shown to release toxic monomers that lead to 
cancer and reproductive abnormalities in humans, rodents, and invertebrates (Wang et al. 2016). Additives in PVC could transfer from medical supplies to humans and indicate that additives could accumulate in the blood (Mettang et al. 1996). In a study conducted by Forte et al. (2016), PS nanoparticles affected cell viability, inflammatory gene expression, and cell morphology of human gastric adenocarcinoma epithelial cells.

$<$ Table 1>

Uptake of plastics specially MPs by humans through inhalation has the potential to cause adverse health effects by particle toxicity, chemical toxicity, and pathogen and parasite vectors (Vethaak and Leslie 2016). The common mechanism of MPs uptake and clearance in the lung is thereby several factors, including hydrophobicity, surface charge, surface functionalisation, the associated protein corona, and particle size, which cause lung injury (Rist et al. 2018). The translocation of smaller particles within the gastrointestinal tract is likely more efficient since nanoparticle PS microspheres found in the blood and organs of rat (Jani et al. 1990). Many of the findings from the particulate materials studies support the notion that micro- or nanometer size of plastic particles could adversely affect human health. Two previous studies observed cellulosic and plastic fibers in human lung tissue which taken from patient with different types of lung cancer (Pauly et al. 1994,1998). Recently, in a study conducted by Chan et al. (2017), a questionnaire survey of 46 workers who used different types of 3D printers by the most frequent printing materials including polylactic acid (64\%), acrylonitrile-butadiene-styrene plastic filaments (27\%) and nylon (23\%) showed respiratory symptoms in $57 \%$ of participants who worked more than $40 \mathrm{~h} /$ week. A work-related interstitial lung disease that induces coughing, dyspnea, and reduction of lung capacity was observed in $4 \%$ of workers from nylon flock plants in the US and Canada (Boag et al. 1999; Eschenbacher et al. 1999). The health impact of MPs exposure has shown in Fig. 2.

$<$ Fig. 2>

Toxic chemical additives in the plastic which are a palpable concern for human health include phthalates, bisphenol A (BPA), brominated flame retardants (BFR), triclosan, bisphenone, and organotins (Galloway 2015). Little information is available on the leaching of additives into biological tissues directly, although Koelmans et al. (2014) showed that additives including nonylphenol (NP) and BPA could leach from plastics ingested by marine organisms. BPA has received considerable press and scientific attention in relation to human health implications (Galloway 2015). At present, BPA is the main chemical used as a monomer for polycarbonate (PC) plastics and in the epoxy resins lining layer of food and beverage cans (Crain et al. 2007). BPA can also be used as an antioxidant or as a 
plasticizer in other polymers (e.g., PP, PE and PVC) (Rani et al. 2015). Several studies have shown that BPA can migrate out of PC and contaminate foodstuffs and drinks (Calafat et al. 2008; Galloway 2015; Guart et al. 2013), and lead to liver function alternation, changes in insulin resistance, development of offspring in the womb of pregnant women, reproductive system and brain function (Srivastava and Godara 2017). BPA acts as an agonist for the estrogen receptors, inhibits thyroid hormone mediated transcription by acting as an antagonist (Moriyama et al. 2002), altered pancreatic beta cell function (Ropero et al. 2008). Adverse human health effects including the onset of obesity and cardiovascular disease (Cipelli et al. 2014; Lang et al. 2008; Melzer et al. 2012) and with numerous reproductive and developmental outcomes (Galloway 2015) were observed in exposure to BPA at levels around 0.2$20 \mathrm{ng} / \mathrm{ml}$ (In the general population with measured urinary BPA). Phthalate esters are applied as plasticizers to enhance the flexibility and durability of various materials and also used in manufacturing of PVC polymers and plastisol (Gómez and Gallart-Ayala 2018). Phthalate esters are potentially harmful when exposed to humans, which may possible cause abnormal sexual development and birth defects (Cheng et al. 2013). Additionally, USEPA classified butyl benzyl phthalate (BBP) and di-2-ethylhexyl phthalate (DEHP) as probable and possible human carcinogens (USEPA, 2007).

\section{MP regulations}

Despite the global attention to plastic pollution and its environmental effects in recent years, there are currently no regulations established yet to manage impacts of secondary MPs. In contrast, many regions have established or implemented regulations to ban production and use of primary MPs, including microbeads, which could reduce MPs entering the aquatic environment (Beat the Microbead 2016; CEPA (Canadian Environmental Protection Act) 2016; Legislative Assembly of Ontario 2015; Pettipas et al. 2016; United States Congress 2015; United Kingdom Department for Environment Food and Rural Affairs 2016), as well as bans or limits on use of single-use macroplastics (e.g. drinks bottles, carrier bags). The first country that declared its intent to produce microbead free cosmetic products was the Netherlands, with a target of 2016. The province of Ontario, Canada, passed legislation to ban the microbeads production in 2015 (Legislative Assembly of Ontario 2015), and since the Canadian federal government classified plastic microbeads as a toxin under the Canadian Environmental Protection Act (CEPA 2016). In December 2015, national legislation was passed by the US Congress to control microbead plastics in the US (United States Congress 2015). Yet, secondary MPs are the major contributors to environmental MP pollution, and therefore, we advocate that new legislation and management policies need to be established to control 
widespread MPs in the environment. In 1973, the International Convention for the Prevention of Pollution from Ships (MARPOL 73/78) was signed, however, a complete ban on the disposal of plastics at sea was not enacted until 1988. Despite the presence of 134 countries to eliminate the plastics disposal at sea, studies have revealed the increasing problem of marine debris since MARPOL 73/78 was signed. Reasons vary depending on jurisdiction, but are most often related to mismanaged waste on land (Xanthos and Walker 2017). The United Nations Environmental Programme (UNEP) has called for immediate action to rid the oceans of MPs as they have noted that MPs are consumed by a wide number of marine organisms, and this leads to both physical and chemical harm (Jiang 2017; UNEP 2014). Therefore, UNEP developed a program by 40 million people from 120 countries, which set up educational procedures to make awareness and encourage the decrease of plastic use, recycling, and evaluate disposal facilities. The United Nations Environment Program/Mediterranean Action Plan (UNEP-MAP), the Oslo/Paris convention (for the protection of the marine environment of the North-East Atlantic (OSPAR), and the Baltic Marine Environment Protection Commission-Helsinki Commission (HELCOM) also have expanded guidelines to evaluate marine litter such as MPs (Jiang 2017). Non-Governmental Organizations (NGOs) have also presented plans to increase awareness and aid to quantify the level of MPs pollution and their impacts at the national and international scales. For example, the 5 Gyres Institute and the Joint Group of Experts on the Scientific Aspects of Marine Environmental Protection engage in awareness campaigns (Xanthos and Walker 2017). Also, on Earth Day 2018, an End Plastic Pollution campaign was launched in response to the substantial increase of plastic waste on our planet. This campaign used the high profile of Earth Day to increase awareness about the issue of plastic pollution and to highlight the issue on the global agenda to demand effective action from governments and individuals for reducing and managing plastic, specifically single-use plastic (Earthday Network 2018). Similarly, there have also been recent studies aimed at highlighting various global strategies to reduce single-use plastic use at national, regional and municipal levels of government, corporations and at the individual level (Schnurr et al. 2018; UNEP 2018). Single-use plastic bag interventions (e.g., bans or levies) have been reported to reduce plastic bag use between 33-96\% which help mitigate single-use plastic marine pollution (Schnurr et al. 2018).

The US and France are the first and second countries respectively to ban MPs from rinse-off cosmetic products with Microbead-Free Waters Act (Kentin 2018; McDevitt et al. 2017). Similarly, this legislation is proposed in Taiwan, South Korea and Sweden, which is waiting for approval and adoption (Kentin 2018). According to the REACH Regulation in the European Union, hazardous substances are regulated to have a high level of protection to human 
health and the environment (European Chemical Agency 2017). Under REACH Regulation any new substance must be registered and evaluated, then can be authorised or restricted, but polymers do not have to be registered so far (Vaughan 2015). The European Commission has to review the exemption by strict criteria to include polymers in the REACH Regulation.

In 2015, the Group of 7 (G7) including Canada, France, Germany, Italy, Japan, the UK, and the US discussed plastic pollution in marine environments and confirmed that marine litter, especially plastic litter, poses a global challenge, which affects aquatic ecosystems and potentially also human health (G7 2015). Hence, they are trying to develop an action plan to combat marine litter and reduce waste from land- and sea-based sources. One of the priorities of the G7 action plan is "Investigating sustainable and cost-effective solutions to reduce and prevent sewage and storm water related waste, including MPs entering the marine environment" (Brennholt et al. 2018). A unique opportunity was provided by Canada's G7 presidency to accelerate domestic action and demonstrate international leadership for reducing use and recycling of single-use plastics to ameliorate marine pollution effected by plastic litter (Walker and Xanthos 2018). In 2018, the ocean plastics charter was adopted by five-member nations of the G7 (Canada, France, Germany, Italy, and the UK) which includes 23 specific actions in five broad categories: (1) sustainable design, production and after-use markets; (2) collection, management and other systems and infrastructure; (3) sustainable lifestyles and education; (4) research, innovation and new technologies; and (5) coastal and shoreline action. The ocean plastics charter includes increasing recycling by at least $50 \%$ in plastic products by 2030 , recycling and reuse of at least $55 \%$ of plastic packaging by 2030 , and to recover $100 \%$ of all plastics by 2040 , and developing research and technologies to remove plastics and MPs from waste water and sewage sludge (G7 2018). In October 2000, the European Union Water Framework Directive (WFD) has been enacted by the European Commission and focuses on "maintaining and improving the aquatic environment in the Community". A Pollution Management and Environmental Health (PMEH) program was established by the World Bank in 2015, which covers technical assistance and financing to decrease pollution and improve health. The Joint Group of Experts on the Scientific Aspects of Marine Environmental Protection (GESAMP) advocates cost-effective way to conduct urgent action to reduce the volume of plastics releasing the ocean by adopting the 3Rs (reduce-reuse-recycle circular economy)(GESAMP 2015). Current Circular economy principles have been extended to include the 6Rs (reuse, recycle, redesign, remanufacture, reduce, recover) (Liu et al. 2018). In this way, the flow of technical materials is returned via society for remanufacturing by a material recovery of products and packaging designed, repair and 
reuse, and where these cases are not suitable, a biological material such as bioplastics may substitute. Today, bioplastics or plant-based plastics are viewed with new interest, which create reliable resources, decoupled from fossil fuels (Bioplastic Feedstock Alliance 2018).

The Packaging and Packaging Waste Directive 94/62/EC (PPWD), and the amending Directive (EU) 2015/720 are about use and reuse of plastic bags and reducing the consumption of lightweight plastic carrier bags (Xanthos and Walker 2017). There are three main directives relevant to the regulation of waste and recycling of plastic bags including the Waste Framework Directive 2008/98/EC (WFD), the Directive on the Landfill of Waste 1999/31/EC and Urban Waste Water Treatment Directive 91/271/EEC. The WFD conduct the Member States on the correct management of their wastes (European Parliament and the Council 2008). It introduces the waste hierarchy, which prioritizes prevention as the first and most important waste management part, followed by reuse/recycling, and finally, disposal/landfilling (European Parliament and the Council 2008). Furthermore, new recycling and recovery purposes for plastics are set with the aim of reusing and recycling at least $50 \%$ of the total plastic waste of households by 2020 (European Parliament and the Council 2008). In 1999, the Directive on the Landfill of Waste 1999/31/EC was implemented to eliminate adverse impacts of the landfills to aquatic ecosystems and human health. At present, there are no restrictions to the quantity of plastic wastes, which deposit as non-hazardous waste in landfills within the Directive of Landfill of Waste (The Council of the European Union 1999), however, the Member States have individually implemented threshold restrictions for disposal of plastic wastes in landfills (PlasticsEurope 2015). In the last decades, several Member States (Germany, Denmark, Sweden, and Austria) banned landfilling of the plastics, which led to significant increase in the recovery of plastic waste in these countries (Steensgaard et al. 2017). The Urban Waste Water Treatment Directive (91/271/EEC) was implemented to maintain and protect aquatic ecosystems, setting thresholds for the discharge of wastewater to the environment to prevent adverse effects such as eutrophication (European Commission 1991).

Extended producer responsibility (EPR) is a public policy strategy that manufacturers are responsible legally and financially to mitigate the environmental impacts of their products throughout its life cycle stages. EPR emerged in Sweden and Germany in the early 1990s and had several desirable and interrelated goals including creating motivations for eco-design of packages and products, using the private sector expertise to reach public targets, internalizing the waste management costs into prices of the products, and shifting waste management costs from municipalities and taxpayers to producers and consumers (Lifset et al. 2013). The EU's Waste of Electrical and 
Electronic Equipment (WEEE) Directive is an example of EPR whereby producers have to return and recycle electronic equipment (Eriksen et al. 2018).

Previous studies revealed significant relationships between personality traits and cognitive abilities with wastemanagement behaviours (Karbalaei et al. 2013, 2014, 2015). For example, Swami et al. (2011) showed that individuals with less machiavellian, less politically cynical, and more conscientious traits showed better waste management behaviours. This may be because conscientiousness is associated with intellectualism and attend to acting based on the dictates of conscience. To the extent that, waste management is realized as a morally-appropriate behaviour, thus, highly conscientious individuals are more responsible to recycle, reuse, and reduce their waste. Similarly, another study conducted by Karbalaei et al. (2015) revealed that individuals with higher spiritual intelligence and lower machiavellianism were more likely to have a positive attitude towards waste-prevention behaviours. Therefore, waste management strategies need to consider personality traits and individual differences that affect environmentalism and could also be considered as a promising strategy to mitigate MP pollutions in the marine and terrestrial environments by improving positive personality traits in consumers, private and government sectors through education. This also could be achieved by education of students in schools and universities as it can provide a long-lasting solution to the environmental problem.

A continued relationship between science and policy can contribute to solutions for mitigation of MPs in the environment. Also, new scientific understanding could help scientists and policymakers to conduct policy-relevant research. Some regulations mentioned in this study are the results of the collaboration between scientists and policymakers which lead to establishing positive changes toward mitigation of MPs. Legislation to ban plastic microbeads is a good illustration of this collaboration because researchers showed that release of microbeads could be easily curbed, and therefore risk to marine life mitigated. Therefore, legislation to ban this source of plastic contamination has been introduced in the US, Canada, the European Union, and Australia (Rochman et al. 2016). In response to this legislation, some manufacturers have agreed to voluntarily remove plastic microbeads from their products (Schnurr et al. 2018). Recently, scientists have developed biodegradable cellulose microbeads from a sustainable source that could be a promising replace of persistent plastics microbeads in a range of applications from personal care products to abrasives (Coombs Obrien et al. 2017) and this could be obliged through legislation in the future. The report of plastic pellets in the oceans, on beaches, and in the digestive systems of seabirds lead to a response of both policy and industry to resolve this problem by Operation Clean Sweep, which was initiated by the 
plastics industry to reduce the loss of plastic pellets to the environment (Rochman et al. 2016). Thus, further studies are required in the area of MPs in order to be able to develop and implement effective management strategies.

Biodegradation of plastic polymers by some organisms such as bacteria, fungi and mealworms are reliable and environmentally safe action plan to tackle plastic pollution that will enable the management of MPs without negative effects. A recent study by Bombelli et al. (2017) showed fast bio-degradation of PE by larvae of the wax moth Galleria mellonella, producing ethylene glycol. Similarly, low-density polyethylene (LDPE) MP particle decayed with isolated bacteria from the gut of the earthworm (Lumbricus errestris) (Lwanga et al. 2018). Therefore, these organisms have prompted significant optimism about the use of "plastic eating organisms" in waste management. Governments need to fund most significantly additional researches and innovations to find organisms that will break down plastic more efficiently.

Collectively, all these strategies help to mitigate the presence of MPs in the terrestrial and aquatic environments. Industry plays a critical role in mitigation of MPs throughout the supply chain. As an example, IKEA has used EPR strategy in its business model by promoting reuse and recycling of materials throughout its supply chain (INGKA Holding 2017). Also, in 2017, Adidas sold 1 million shoes made from plastic debris, equivalent to 16.5 million plastic bottles and $14.3 \mathrm{t}$ of nylon gill nets (Kharpal 2018). Improvements of circular economy principles such as recycling and waste management strategies can also be a catalyst in the reduction of plastic consumption with strong direct and indirect socioeconomic and environmental implications. Plastic pollution mitigation through coastal and ocean cleanups are important immediate activities that are needed to help reduce marine plastic pollution. Plastic bag bans can effectively reduce overuse of single-use plastic and following that mitigating plastic and MPs pollutions if properly implemented and managed (Schnurr et al. 2018). Besides, plastic manufacturers must ensure that their products are standardized and labelled properly to facilitate recycling. Furthermore, increasing awareness through universities, school, organizations and networks about MPs issues by campaigns and educate personal responsibility of individuals for mitigating plastic and MPs pollution by choosing to reject, reduce, reuse and recycling of plastics. Educational intervention (e.g., marine litter education) to children boosts their awareness, perceptions of consequences and self-reported action (Hartley et al. 2015).

\section{Conclusion}


MPs are very tiny particles of plastics that find their way into the environment through primary and secondary sources. The presence of MPs in air, soil, and particularly in aquatic environments have become the focus of a dearth of environmental pollution research. This, combined with recent discoveries of MPs in plates of seafood, sea salt, canned fish, bottled water, tap water, honey, and sugar is an emerging area of concern related to the potential impacts of this plastic debris to human health. Potential health concerns have been related to the toxicity of harmful chemicals sorbed from the environment or from additives that are used in the plastic production process itself. As this review showed, lack of studies on MPs impacts on humans highlight the need for more studies focusing on human health risk assessment of MPs. Recently, some national regulations have been proposed or established to help reduce MPs in the environment. However, there are currently no regulations established to manage impacts from secondary MPs (fragments from larger plastic items). Involving the general public, the media, the socioeconomic sectors, tourism, and companies is necessary to tackle the issue. New propose, new national and international regulations should be established to prevent the exceeding critical environmental threshold concentrations. Implementing internationally harmonized regulations across developed and developing countries such as the circular economy could help proper waste management. Policies to reduce single-use plastics including, bans of single-use plastic bags, drinking straws, deposit and return plans for plastic bottles, and EPR, which makes manufactures responsible for the entire product life-cycle, are positive steps that should be widely implemented.

\section{Acknowledgements}

This work was supported by Iran National Science Foundation (INSF), Tehran; grant number 97001707. 


\section{References}

Akhbarizadeh R, Moore F, Keshavarzi B (2018) Investigating a probable relationship between microplastics and potentially toxic elements in fish muscles from northeast of Persian Gulf. Environ Pollut 232:154-163

Albertsson A-C (1980) The shape of the biodegradation curve for low and high density polyethenes in prolonged series of experiments. Eur Polym J 16:623-630

Ali MI, Ahmed S, Robson G, et al (2014) Isolation and molecular characterization of polyvinyl chloride (PVC) plastic degrading fungal isolates. J Basic Microbiol 54:18-27

Alvarenga P, Farto M, Mourinha C, Palma P (2016) Beneficial use of dewatered and composted sewage sludge as soil amendments: behaviour of metals in soils and their uptake by plants. Waste Biomass Valorization $7: 1189-1201$

Alzona J, Cohen BL, Rudolph H, et al (1979) Indoor-outdoor relationships for airborne particulate matter of outdoor origin. Atmospheric Environ 1967 13:55-60

Andrady AL (2011) Microplastics in the marine environment. Mar Pollut Bull 62:1596-1605

Andrady AL (2015) Persistence of plastic litter in the oceans. In: Marine anthropogenic litter. Springer, pp 57-72

Arkatkar A, Arutchelvi J, Bhaduri S, et al (2009) Degradation of unpretreated and thermally pretreated polypropylene by soil consortia. Int Biodeterior Biodegrad 63:106-111

Arthur C, Baker JE, Bamford HA (2009) Proceedings of the International Research Workshop on the Occurrence, Effects, and Fate of Microplastic Marine Debris, September 9-11, 2008, University of Washington Tacoma, Tacoma, WA, USA

Auta HS, Emenike CU, Fauziah SH (2017) Distribution and importance of microplastics in the marine environment: A review of the sources, fate, effects, and potential solutions. Environ Int 102, 165-176

Avery-Gomm S, Provencher JF, Liboiron M, et al (2018) Plastic pollution in the Labrador Sea: An assessment using the seabird northern fulmar Fulmarus glacialis as a biological monitoring species. Mar Pollut Bull 127:817822

Baalkhuyur FM, Dohaish E-JAB, Elhalwagy ME, et al (2018) Microplastic in the gastrointestinal tract of fishes along the Saudi Arabian Red Sea coast. Mar Pollut Bull 131:407-415

Barnes DK, Galgani F, Thompson RC, Barlaz M (2009) Accumulation and fragmentation of plastic debris in global environments. Philos Trans R Soc B Biol Sci 364:1985-1998 
Barnes DKA, Walters A, Gonçalves L (2010) Macroplastics at sea around Antarctica. Mar Environ Res 70:250-252

Barboza LGA, Cózar A, Gimenez BC, et al (2019) Macroplastics Pollution in the Marine Environment. In: World Seas: an Environmental Evaluation. Elsevier, pp 305-328

Batel A, Linti F, Scherer M, et al (2016) Transfer of benzo [a] pyrene from microplastics to Artemia nauplii and further to zebrafish via a trophic food web experiment: CYP1A induction and visual tracking of persistent organic pollutants. Environ Toxicol Chem 35:1656-1666

Baulch S, Perry C (2014) Evaluating the impacts of marine debris on cetaceans. Mar Pollut Bull 80:210-221

Beat the Microbead (2016) The Netherlands is leading; prelude to a European ban on microplastics. Retrieved from http://www.beatthemicrobead.org/en/politics.

Bergmann M, Wirzberger V, Krumpen T, et al (2017) High quantities of microplastic in Arctic deep-sea sediments from the HAUSGARTEN observatory. Environ Sci Technol 51:11000-11010

Bessa F, Barría P, Neto JM, et al (2018a) Microplastics in Juvenile Commercial Fish from an Estuarine Environment. In: Proceedings of the International Conference on Microplastic Pollution in the Mediterranean Sea. Springer, pp 131-135

Bessa F, Barría P, Neto JM, et al (2018b) Occurrence of microplastics in commercial fish from a natural estuarine environment. Mar Pollut Bull 128:575-584

Betts K (2008) Why small plastic particles may pose a big problem in the oceans. ACS Publications. Environ. Sci. Technol., 42 (24), 8995-8995

Biginagwa FJ, Mayoma BS, Shashoua Y, et al (2016) First evidence of microplastics in the African Great Lakes: Recovery from Lake Victoria Nile perch and Nile tilapia. J Gt Lakes Res 42:146-149

Bioplastic Feedstock Alliance (2018) Encouraging the responsible development of plant-based plastics. http://bioplasticfeedstockalliance.org/.Accessed 10 Oct 2018

Boag AH, Colby TV, Fraire AE, et al (1999) The pathology of interstitial lung disease in nylon flock workers. Am J Surg Pathol 23:1539

Bombelli P, Howe CJ, Bertocchini F (2017) Polyethylene bio-degradation by caterpillars of the wax moth Galleria mellonella. Curr Biol 27: R292-R293

Boren LJ, Morrissey M, Muller CG, Gemmell NJ (2006) Entanglement of New Zealand fur seals in man-made debris at Kaikoura, New Zealand. Mar Pollut Bull 52:442-446 
Bos RP, Sutton TT, Frank TM (2018) Appraisal of Microplastic Ingestion in Deep-Pelagic Fishes and Crustaceans in the Northern Gulf of Mexico and Straits of Florida

Bråte ILN, Eidsvoll DP, Steindal CC, Thomas KV (2016) Plastic ingestion by Atlantic cod (Gadus morhua) from the Norwegian coast. Mar Pollut Bull 112:105-110

Brennholt N, Hels s M, Reifferscheid G (2018) Freshwater microplastics: challenges for regulation and management. In: Freshwater Microplastics. Springer, pp 239-272

Browne MA, Crump P, Niven SJ, et al (2011) Accumulation of microplastic on shorelines woldwide: sources and sinks. Environ Sci Technol 45:9175-9179

Browne MA, Galloway T, Thompson R (2007) Microplastic_an emerging contaminant of potential concern? Integr Environ Assess Manag 3:559-561

Browne MA, Galloway TS, Thompson RC (2010) Spatial patterns of plastic debris along estuarine shorelines. Environ Sci Technol 44:3404-3409

Calafat AM, Ye X, Wong L-Y, et al (2008) Exposure of the US population to bisphenol A and 4-tertiaryoctylphenol: 2003-2004. Environ Health Perspect 116:39

Carpenter EJ, Smith KL (1972) Plastics on the Sargasso Sea surface. Science 175:1240-1241

Catarino AI, Macchia V, Sanderson WG, et al (2018) Low levels of microplastics (MP) in wild mussels indicate that MP ingestion by humans is minimal compared to exposure via household fibres fallout during a meal. Environ Pollut 237:675-684

CEPA (Canadian Environmental Protection Act) (2016) SOR/2016-150. June 17, 2016. Retrieved from http://www.gazette.gc.ca/rp-pr/p2/2016/2016-06-29/html/ sor-dors150-eng.php

Cesa FS, Turra A, Baruque-Ramos J (2017) Synthetic fibers as microplastics in the marine environment: a review from textile perspective with a focus on domestic washings. Sci Total Environ 598:1116-1129

César MEF, Mariani P, Innocentini-Mei LH, Cardoso E (2009) Particle size and concentration of poly ( $\varepsilon$ caprolactone) and adipate modified starch blend on mineralization in soils with differing textures. Polym Test 28:680-687

Chan F, Rajaram N, House R, et al (2017) Potential respiratory effects from 3-D printing. In: B58. Occupational lung disease: case studies, epidemiology, and mechanisms. American Thoracic Society, pp A3861-A3861 
Cheng Z, Nie X-P, Wang H-S, Wong M-H (2013) Risk assessments of human exposure to bioaccessible phthalate esters through market fish consumption. Environ Int 57-58:75-80

Cincinelli A, Scopetani C, Chelazzi D, et al (2017) Microplastic in the surface waters of the Ross Sea (Antarctica): occurrence, distribution and characterization by FTIR. Chemosphere 175:391-400

Cipelli R, Harries L, Okuda K, et al (2014) Bisphenol A modulates the metabolic regulator oestrogen-related receptor- $\alpha$ in T-cells. Reproduction 147:419-426

Claessens M, De Meester S, Van Landuyt L, et al (2011) Occurrence and distribution of microplastics in marine sediments along the Belgian coast. Mar Pollut Bull 62:2199-2204

Cole M, Lindeque P, Halsband C, Galloway TS (2011) Microplastics as contaminants in the marine environment: a review. Mar Pollut Bull 62:2588-2597

Cole M, Lindeque P, Fileman E, et al (2013) Microplastic ingestion by zooplankton. Environ Sci Technol 47:66466655

Colton JB, Knapp FD, Burns BR (1974) Plastic particles in surface waters of the northwestern Atlantic. Science $185: 491-497$

Compa M, Ventero A, Iglesias M, Deudero S (2018) Ingestion of microplastics and natural fibres in Sardina pilchardus (Walbaum, 1792) and Engraulis encrasicolus (Linnaeus, 1758) along the Spanish Mediterranean coast. Mar Pollut Bull 128:89-96

Coombs OBrien J, Torrente-Murciano L, Mattia D, Scott JL (2017) Continuous production of cellulose microbeads via membrane emulsification. ACS Sustain Chem Eng 5:5931-5939

Corcoran PL, Biesinger MC, Grifi M (2009) Plastics and beaches: a degrading relationship. Mar Pollut Bull 58:8084

Crain DA, Eriksen M, Iguchi T, et al (2007) An ecological assessment of bisphenol-A: evidence from comparative biology. Reprod Toxicol 24:225-239

Dantas DV, Barletta M, Da Costa MF (2012) The seasonal and spatial patterns of ingestion of polyfilament nylon fragments by estuarine drums (Sciaenidae). Environ Sci Pollut Res 19:600-606

De Souza Machado AAS, Lau CW, Till J, et al (2018) Impacts of microplastics on the soil biophysical environment. Environ Sci Technol. 52: 9656-9665

Derraik JG (2002) The pollution of the marine environment by plastic debris: a review. Mar Pollut Bull 44:842-852 
Desforges J-PW, Galbraith M, Dangerfield N, Ross PS (2014) Widespread distribution of microplastics in subsurface seawater in the NE Pacific Ocean. Mar Pollut Bull 79:94-99

Devriese LI, van der Meulen MD, Maes T, et al (2015) Microplastic contamination in brown shrimp (Crangon crangon, Linnaeus 1758) from coastal waters of the Southern North Sea and Channel area. Mar Pollut Bull 98:179-187

Driedger AG, Dürr HH, Mitchell K, Van Cappellen P (2015) Plastic debris in the Laurentian Great Lakes: a review. J Gt Lakes Res 41:9-19

Dris R, Gasperi J, Mirande C, et al (2017) A first overview of textile fibers, including microplastics, in indoor and outdoor environments. Environ Pollut 221:453-458

Dris R, Gasperi J, Rocher V, et al (2015) Microplastic contamination in an urban area: a case study in Greater Paris. Environ Chem 12:592-599

Dris R, Gasperi J, Saad M, et al (2016) Synthetic fibers in atmospheric fallout: a source of microplastics in the environment? Mar Pollut Bull 104:290-293

Dubaish F, Liebezeit G (2013) Suspended microplastics and black carbon particles in the Jade system, southern North Sea. Water Air Soil Pollut 224:1352

Duis K, Coors A (2016) Microplastics in the aquatic and terrestrial environment: sources (with a specific focus on personal care products), fate and effects. Environ Sci Eur 28:2

Eerkes-Medrano D, Thompson RC, Aldridge DC (2015) Microplastics in freshwater systems: a review of the emerging threats, identification of knowledge gaps and prioritisation of research needs. Water Res 75:6382

Earthday Network (2018) End plastic pollution. https://www.earthday.org/campaigns/plastics/plastics-campaign/

Eriksen M, Mason S, Wilson S, et al (2013) Microplastic pollution in the surface waters of the Laurentian Great Lakes. Mar Pollut Bull 77:177-182

Eriksen M, Thiel M, Prindiville M, Kiessling T (2018) Microplastic: What Are the Solutions? In: Freshwater Microplastics. Springer, pp 273-298

Eschenbacher WL, Kreiss K, Lougheed MD, et al (1999) Nylon flock-associated interstitial lung disease. Am J Respir Crit Care Med 159:2003-2008 
European Chemical Agency (2017) REACH. Available on: https://echa.europa.eu/regulations/reach, Accessed on: $04 / 24 / 2017$

European Commission (1991) Council Directive of 21 May 1991 concerning urban wastewater treatment (91/271/EEC). Off. J. Eur. Communities L 135/40.

European Parliament and the Council (2008) Directive 2008/98/EC of the European Parliament and of the Council of 19 november 2008 on waste and repealing certain directives. Off. J. Eur. Communities L312/3, 3e30

Fernando HJS, Lee SM, Anderson J, et al (2001) Urban fluid mechanics: air circulation and contaminant dispersion in cities. Environ Fluid Mech 1:107-164

Ferreira P, Fonte E, Soares ME, et al (2016) Effects of multi-stressors on juveniles of the marine fish Pomatoschistus microps: gold nanoparticles, microplastics and temperature. Aquat Toxicol 170:89-103

Foekema EM, De Gruijter C, Mergia MT, et al (2013) Plastic in North Sea fish. Environ Sci Technol 47:8818-8824

Forte M, Iachetta G, Tussellino M, et al (2016) Polystyrene nanoparticles internalization in human gastric adenocarcinoma cells. Toxicol In Vitro 31:126-136

Fossi MC, Panti C, Guerranti C, et al (2012) Are baleen whales exposed to the threat of microplastics? A case study of the Mediterranean fin whale (Balaenoptera physalus). Mar Pollut Bull 64:2374-2379

Fossi MC, Marsili L, Baini M, et al (2016) Fin whales and microplastics: The Mediterranean Sea and the Sea of Cortez scenarios. Environ Pollut 209:68-78

France R (2016) Reinterpreting nineteenth-century accounts of whales battling 'sea serpents' as an illation of early entanglement in pre-plastic fishing gear or maritime debris. Int J Marit Hist 28:686-714

Free CM, Jensen OP, Mason SA, et al (2014) High-levels of microplastic pollution in a large, remote, mountain lake. Mar Pollut Bull 85:156-163

Fuller S, Gautam A (2016) A procedure for measuring microplastics using pressurized fluid extraction. Environ Sci Technol 50:5774-5780

G7 (2015) Leaders' Declaration G7 Summit, 7-8 June 2015. Schloss Elmau, Germany, pp 17-18

G7 (2018) Ocean plastics charter, https://g7.gc.ca/wp-content/uploads/2018/06/OceanPlasticsCharter.pdf, pp 2-4

Galgani F, Hanke G, Maes T (2015) Global distribution, composition and abundance of marine litter. In: Marine anthropogenic litter. Springer, pp 29-56 
Galloway TS (2015) Micro-and nano-plastics and human health. In: Marine anthropogenic litter. Springer, pp 343366

Gasperi J, Wright SL, Dris R, et al (2018) Microplastics in air: Are we breathing it in? Curr Opin Environ Sci Health $1: 1-5$

GESAMP (2016) Sources, fate and effects of microplastics in the marine environment: a global assessment. In: Kershaw, P.J., Rochmann, C.M. (Eds.), IMO/FAO/ UNESCOIOC/UNIDO/WMO/IAEA/UN/UNEP/UNDP Joint Group of Experts on the Scientific Aspects of Marine Environmental Protection, p. 220.

GESAMP (2015) Sources, fate and effects of microplastics in the marine environment: a global assessment. Reports and Studies 90. London: IMO/FAO/UNESCOIOC/ UNIDO/WMO/IAEA/UN/UNEP/UNDP Joint Group of Experts on the Scientific Aspects of Marine Environmental Protection.

Geyer R, Jambeck JR, Law KL (2017) Production, use, and fate of all plastics ever made. Sci Adv 3:e1700782

Gies EA, LeNoble JL, Noël M, et al (2018) Retention of microplastics in a major secondary wastewater treatment plant in Vancouver, Canada. Mar Pollut Bull 133:553-561. doi: 10.1016/j.marpolbul.2018.06.006

Gómez C, Gallart-Ayala H (2018) Metabolomics: a tool to characterize the effect of Phthalates and Bisphenol A. Environ Rev. doi: 10.1139/er-2018-0010

Graham ER, Thompson JT (2009) Deposit-and suspension-feeding sea cucumbers (Echinodermata) ingest plastic fragments. J Exp Mar Biol Ecol 368:22-29

Green DS (2016) Effects of microplastics on European flat oysters, Ostrea edulis and their associated benthic communities. Environ Pollut 216:95-103

Gregory MR (1996) Plastic 'scrubbers' in hand cleansers: a further (and minor) source for marine pollution identified. Mar Pollut Bull 32:867-871

Guart A, Wagner M, Mezquida A, et al (2013) Migration of plasticisers from $\operatorname{Tritan}^{\mathrm{TM}}$ and polycarbonate bottles and toxicological evaluation. Food Chem 141:373-380

Halstead JE, Smith JA, Carter EA, et al (2018) Assessment tools for microplastics and natural fibres ingested by fish in an urbanised estuary. Environ Pollut 234:552-561

Hartley BL, Thompson RC, Pahl S (2015) Marine litter education boosts children's understanding and self-reported actions. Mar Pollut Bull 90:209-217 
Herrera A, Asensio M, Martínez I, et al (2017) Microplastic and tar pollution on three Canary Islands beaches: An annual study. Mar Pollut Bull. 129, 494-502

Horton AA, Svendsen C, Williams RJ, et al (2017a) Large microplastic particles in sediments of tributaries of the River Thames, UK-Abundance, sources and methods for effective quantification. Mar Pollut Bull $114: 218-226$

Horton AA, Walton A, Spurgeon DJ, et al (2017b) Microplastics in freshwater and terrestrial environments: evaluating the current understanding to identify the knowledge gaps and future research priorities. Sci Total Environ 586:127-141

Huerta Lwanga E, Gertsen H, Gooren H, et al (2016) Microplastics in the terrestrial ecosystem: implications for Lumbricus terrestris (Oligochaeta, Lumbricidae). Environ Sci Technol 50:2685-2691

Imhof HK, Ivleva NP, Schmid J, et al (2013) Contamination of beach sediments of a subalpine lake with microplastic particles. Curr Biol 23:R867-R868

Imhof HK, Wiesheu AC, Anger PM, et al (2018) Variation in plastic abundance at different lake beach zones-A case study. Sci Total Environ 613:530-537

Iñiguez ME, Conesa JA, Fullana A (2017) Microplastics in Spanish Table Salt. Sci Rep 7:8620

INGKA Holding GV (2017) Sustainability summary report FY17. Ikea. 2017. http://www.ikea.com/gb/en/doc/ikea2017-ikea-groupsustainability-summary-report_1364488103883.pdf

International Maritime Organization (2015) Plastic particles in the ocean may be as harmful as plastic bags, report says. International Maritime Organization Press Briefing Archives. 27/04/2015

Isobe A, Uchiyama-Matsumoto K, Uchida K, Tokai T (2017) Microplastics in the Southern Ocean. Mar Pollut Bull $114: 623-626$

Jambeck JR, Geyer R, Wilcox C, et al (2015) Plastic waste inputs from land into the ocean. Science 347:768-771

Jang, Y.C., Hong, S., Lee, J., Lee, M.J., Shim, W.J (2014) Estimation of lost tourism revenue in Geoje Island from the 2011 marine debris pollution event in South Korea. Mar. Pollut. Bull. 81, 49-54

Jani P, Halbert GW, Langridge J, Florence AT (1990) Nanoparticle uptake by the rat gastrointestinal mucosa: quantitation and particle size dependency. J Pharm Pharmacol 42:821-826

Jiang, J-Q (2017) Occurrence of microplastics and its pollution in the environment: A review. Sustain. Prod. Consum. 13:16-23 
Karami A, Golieskardi A, Choo CK, et al (2017a) The presence of microplastics in commercial salts from different countries. Sci. Rep. 7: 46173

Karami A, Golieskardi A, Choo CK, et al (2018) Microplastic and mesoplastic contamination in canned sardines and sprats. Sci Total Environ 612:1380-1386

Karami A, Golieskardi A, Ho YB, et al (2017b) Microplastics in eviscerated flesh and excised organs of dried fish. Sci. Rep. 7:5473.

Karbalaei S, Abdollahi A, Abdullah S (2015) Machiavellianism and Spiritual Intelligence as Predictors of WastePrevention Behaviours among Malaysian University Students. Pertanika J Soc Sci Humanit 23:

Karbalaei S, Abdollahi A, Abu M, et al (2013) Locus of control, problem-solving skills appraisal as predictors of waste prevention behaviors. Romanian J Appl Psychol 15:51-58

Karbalaei S, Abdollahi A, Momtaz V, Abu Talib M (2014) Locus of control, neuroticism, and spirituality as predictors of waste-prevention behaviors. Ecopsychology 6:252-259

Karlsson TM, Vethaak AD, Almroth BC, et al (2017) Screening for microplastics in sediment, water, marine invertebrates and fish: method development and microplastic accumulation. Mar Pollut Bull 122:403-408

Kaur S, Nieuwenhuijsen MJ, Colvile RN (2007) Fine particulate matter and carbon monoxide exposure concentrations in urban street transport microenvironments. Atmos Environ 41:4781-4810

Kentin E (2018) Banning Microplastics in Cosmetic Products in Europe: Legal Challenges. In: Proceedings of the International Conference on Microplastic Pollution in the Mediterranean Sea. Springer, pp 245-250

Kharpal A (2018) Adidas sold 1 million shoes made out of ocean plastic in 2017. CNBC. https://www.cnbc.com/2018/03/14/adidas-sold-1-million-shoes-made-out-of-ocean-plastic-in-2017.html

Koelmans AA, Besseling E, Foekema EM (2014) Leaching of plastic additives to marine organisms. Environ Pollut $187: 49-54$

Kolandhasamy P, Su L, Li J, et al (2018) Adherence of microplastics to soft tissue of mussels: A novel way to uptake microplastics beyond ingestion. Sci Total Environ 610:635-640

Kosuth M, Wattenberg EV, Mason SA, et al (2017) Synthetic polymer contamination in global drinking water. Orb Media

La Daana KK, Officer R, Lyashevska O, et al (2017) Microplastic abundance, distribution and composition along a latitudinal gradient in the Atlantic Ocean. Mar Pollut Bull 115:307-314 
Lachenmeier DW, Kocareva J, Noack D, Kuballa T (2015) Microplastic identification in German beer-an artefact of laboratory contamination? Dtsch Lebensm-Rundsch 111:437-440

Lang IA, Galloway TS, Scarlett A, et al (2008) Association of urinary bisphenol A concentration with medical disorders and laboratory abnormalities in adults. Jama 300:1303-1310

Legislative Assembly of Ontario (2015) Bill 75, Microbead Elimination and Monitoring Act, 2015.

Lei K, Qiao F, Liu Q, et al (2017) Microplastics releasing from personal care and cosmetic products in China. Mar Pollut Bull 123:122-126

Li H-X, Ma L-S, Lin L, et al (2018) Microplastics in oysters Saccostrea cucullata along the Pearl River Estuary, China. Environ Pollut 236:619-625

Li J, Yang D, Li L, et al (2015) Microplastics in commercial bivalves from China. Environ Pollut 207:190-195

Li WC, Tse HF, Fok L (2016) Plastic waste in the marine environment: A review of sources, occurrence and effects. Sci Total Environ 566:333-349

Liebezeit G, Liebezeit E (2013) Non-pollen particulates in honey and sugar. Food Addit Contam Part A 30:21362140

Liebezeit G, Liebezeit E (2014) Synthetic particles as contaminants in German beers. Food Addit Contam Part A $31: 1574-1578$

Liebezeit G, Liebezeit E (2015) Origin of synthetic particles in honeys. Pol J Food Nutr Sci 65:143-147

Lifset R, Atasu A, Tojo N (2013) Extended producer responsibility: national, international, and practical perspectives. J Ind Ecol 17:162-166

Lithner D, Larsson $\AA$, Dave G (2011) Environmental and health hazard ranking and assessment of plastic polymers based on chemical composition. Sci Total Environ 409:3309-3324

Liu Z, Adams M, Walker TR (2018) Are exports of recyclables from developed to developing countries waste pollution transfer or part of the global circular economy? Resour Conserv Recycl 136:22-23

Lechner A, Keckeis H, Lumesberger-Loisl F, et al (2014) The Danube so colourful: a potpourri of plastic litter outnumbers fish larvae in Europe's second largest river. Environ Pollut 188:177-181

Lopez Lozano R, Mouat J (2009) Marine litter in the Northeast Atlantic Region: assessment and priorities for response. KIMO International Grantfield, UK. pp. 5-14 
Lusher AL, McHugh M, Thompson RC (2013) Occurrence of microplastics in the gastrointestinal tract of pelagic and demersal fish from the English Channel. Mar Pollut Bull 67:94-99

Lusher AL, Burke A, O’Connor I, Officer R (2014) Microplastic pollution in the Northeast Atlantic Ocean: validated and opportunistic sampling. Mar Pollut Bull 88:325-333

Lusher AL, Tirelli V, O’Connor I, Officer R (2015) Microplastics in Arctic polar waters: the first reported values of particles in surface and sub-surface samples. Sci Rep 5:14947

Lusher AL, Welden NA, Sobral P, Cole M (2017) Sampling, isolating and identifying microplastics ingested by fish and invertebrates. Anal Methods 9:1346-1360

Lwanga EH, Thapa B, Yang X, et al (2018) Decay of low-density polyethylene by bacteria extracted from earthworm's guts: A potential for soil restoration. Sci Total Environ 624:753-757

Magnusson K, Norén F (2014) Screening of microplastic particles in and down-stream a wastewater treatment plant. c55, 1-22

Mani T, Hauk A, Walter U, Burkhardt-Holm P (2015) Microplastics profile along the Rhine River. Sci Rep 5:17988

Mathalon A, Hill P (2014) Microplastic fibers in the intertidal ecosystem surrounding Halifax Harbor, Nova Scotia. Mar Pollut Bull 81:69-79

Mascarenhas R, Santos R, Zeppelini D (2004) Plastic debris ingestion by sea turtle in Paraíba, Brazil. Mar Pollut Bull 49:354-355

Mason SA, Garneau D, Sutton R, et al (2016) Microplastic pollution is widely detected in US municipal wastewater treatment plant effluent. Environ Pollut 218:1045-1054

McDevitt JP, Criddle CS, Morse M, et al (2017) Addressing the Issue of Microplastics in the Wake of the Microbead-Free Waters Act A New Standard Can Facilitate Improved Policy. Environ. Sci. Technol., 51: 6611-6617

McGoran AR, Clark PF, Morritt D (2017) Presence of microplastic in the digestive tracts of European flounder, Platichthys flesus, and European smelt, Osmerus eperlanus, from the River Thames. Environ Pollut 220:744-751

Melzer D, Osborne NJ, Henley WE, et al (2012) Urinary Bisphenol A Concentration and Risk of Future Coronary Artery Disease in Apparently Healthy Men and WomenClinical Perspective. Circulation 125:1482-1490 
Mettang T, Thomas S, Kiefer T, et al (1996) Uraemic pruritus and exposure to di (2-ethylhexyl) phthalate (DEHP) in haemodialysis patients. Nephrol Dial Transplant 11:2439-2443

Mintenig SM, Int-Veen I, Löder MG, et al (2017) Identification of microplastic in effluents of waste water treatment plants using focal plane array-based micro-Fourier-transform infrared imaging. Water Res 108:365-372

Mohamed Nor NH, Obbard JP (2014) Microplastics in Singapore's coastal mangrove ecosystems. Mar Pollut Bull 79:278-283

Moore JD, Ototake M, Nakanishi T (1998) Particulate antigen uptake during immersion immunisation of fish: the effectiveness of prolonged exposure and the roles of skin and gill. Fish Shellfish Immunol. 8: 393-408

Moriyama K, Tagami T, Akamizu T, et al (2002) Thyroid hormone action is disrupted by bisphenol A as an antagonist. J Clin Endocrinol Metab 87:5185-5190

Muise I, Adams M, Côté R, Price GW (2016) Attitudes to the recovery and recycling of agricultural plastics waste: A case study of Nova Scotia, Canada. Resour Conserv Recycl 109:137-145

Mühlschlegel P, Hauk A, Walter U, Sieber R (2017) Lack of evidence for microplastic contamination in honey. Food Addit Contam Part A 34:1982-1989

Munari C, Infantini V, Scoponi M, et al (2017) Microplastics in the sediments of Terra Nova Bay (Ross Sea, Antarctica). Mar Pollut Bull 122:161-165. doi: 10.1016/j.marpolbul.2017.06.039

Murphy F, Ewins C, Carbonnier F, Quinn B (2016) Wastewater treatment works (WwTW) as a source of microplastics in the aquatic environment. Environ Sci Technol 50:5800-5808

Naji A, Esmaili Z, Khan FR (2017) Plastic debris and microplastics along the beaches of the Strait of Hormuz, Persian Gulf. Mar Pollut Bull 114:1057-1062

Naji A, Nuri M, Vethaak AD (2018) Microplastics contamination in molluscs from the northern part of the Persian Gulf. Environ Pollut 235:113-120

Neves D, Sobral P, Ferreira JL, Pereira T (2015) Ingestion of microplastics by commercial fish off the Portuguese coast. Mar Pollut Bull 101:119-126

Ng KL, Obbard JP (2006) Prevalence of microplastics in Singapore's coastal marine environment. Mar Pollut Bull $52: 761-767$

Nizzetto L, Langaas S, Futter M (2016) Do microplastics spill on to farm soils? Nature. 537, 488 
Obbard RW, Sadri S, Wong YQ, et al (2014) Global warming releases microplastic legacy frozen in Arctic Sea ice. Earths Future 2:315-320

O'Hanlon NJ, James NA, Masden EA, Bond AL (2017) Seabirds and marine plastic debris in the northeastern Atlantic: A synthesis and recommendations for monitoring and research. Environ Pollut 231:1291-1301

Otake Y, Kobayashi T, Asabe H, et al (1995) Biodegradation of low-density polyethylene, polystyrene, polyvinyl chloride, and urea formaldehyde resin buried under soil for over 32 years. J Appl Polym Sci 56:1789-1796

Patel MM, Goyal BR, Bhadada SV, et al (2009) Getting into the brain. CNS Drugs 23:35-58

Pauly JL, Rodriguez MI, Falzone CM, et al (1994) Methods for viewing, identifying, and enumerating natural and synthetic fibers in human lungs. Am. J. Respir. Cnt. Care Med., 149: A8IO.

Pauly JL, Stegmeier SJ, Allaart HA, et al (1998) Inhaled cellulosic and plastic fibers found in human lung tissue. Cancer Epidemiol Prev Biomark 7:419-428

Pazos RS, Maiztegui T, Colautti DC, et al (2017) Microplastics in gut contents of coastal freshwater fish from Río de la Plata estuary. Mar Pollut Bull 122:85-90

Pettipas S, Bernier M, Walker TR (2016) A Canadian policy framework to mitigate plastic marine pollution. Mar Policy 68:117-122

Phuong NN, Zalouk-Vergnoux A, Poirier L, et al (2016) Is there any consistency between the microplastics found in the field and those used in laboratory experiments? Environ Pollut 211:111-123

PlasticsEurope (2017) Plastics - the Facts 2017: An analysis of European plastic production, demand and waste data Brussels, Belgium. 16

PlasticsEurope (2015) Plastics Manufacturers Call for Ban on Landfill in Europe. http://www.plasticseurope.org/information-centre/news/news-2011/plasticsmanufacturers-call-for-ban-onlandfill-in-europe.aspx (Accessed 05.04.2016)

Possatto FE, Barletta M, Costa MF, et al (2011) Plastic debris ingestion by marine catfish: an unexpected fisheries impact. Mar Pollut Bull 62:1098-1102

Prata JC (2018a) Microplastics in wastewater: State of the knowledge on sources, fate and solutions. Mar Pollut Bull 129:262-265. doi: 10.1016/j.marpolbul.2018.02.046

Prata JC (2018b) Airborne microplastics: Consequences to human health? Environ Pollut 234:115-126 
Provencher JF, Vermaire JC, Avery-Gomm S, et al (2018) Garbage in guano? Microplastic debris found in faecal precursors of seabirds known to ingest plastics. Sci Total Environ 644:1477-1484

Rani M, Shim WJ, Han GM, et al (2015) Qualitative analysis of additives in plastic marine debris and its new products. Arch Environ Contam Toxicol 69:352-366

Rillig MC (2012) Microplastic in terrestrial ecosystems and the soil? Environ. Sci. Technol. 46: 6453-6454

Rillig MC, Ziersch L, Hempel S (2017) Microplastic transport in soil by earthworms. Sci Rep 7:1362

Rist S, Almroth BC, Hartmann NB, Karlsson TM (2018) A critical perspective on early communications concerning human health aspects of microplastics. Sci Total Environ 626:720-726

Rochman CM, Cook A-M, Koelmans AA (2016) Plastic debris and policy: Using current scientific understanding to invoke positive change. Environ Toxicol Chem 35:1617-1626

Rochman CM, Hoh E, Kurobe T, Teh SJ (2013) Ingested plastic transfers hazardous chemicals to fish and induces hepatic stress. Sci Rep 3:3263

Rochman CM, Tahir A, Williams SL, et al (2015) Anthropogenic debris in seafood: Plastic debris and fibers from textiles in fish and bivalves sold for human consumption. Sci Rep 5:14340

Ropero AB, Alonso-Magdalena P, García-García E, et al (2008) Bisphenol-A disruption of the endocrine pancreas and blood glucose homeostasis. Int J Androl 31:194-200

Rummel CD, Löder MG, Fricke NF, et al (2016) Plastic ingestion by pelagic and demersal fish from the North Sea and Baltic Sea. Mar Pollut Bull 102:134-141

Ryan PG, Moore CJ, van Franeker JA, Moloney CL (2009) Monitoring the abundance of plastic debris in the marine environment. Philos Trans R Soc B Biol Sci 364:1999-2012

Sanchez W, Bender C, Porcher J-M (2014) Wild gudgeons (Gobio gobio) from French rivers are contaminated by microplastics: preliminary study and first evidence. Environ Res 128:98-100

Santana VT, Goncalves SPC, Agnelli JAM, Martins-Franchetti SM (2012) Biodegradation of a polylactic acid/polyvinyl chloride blend in soil. J Appl Polym Sci 125:536-540

Scarascia-Mugnozza G, Sica C, Russo G (2012) Plastic materials in European agriculture: actual use and perspectives. J Agric Eng 42:15-28

Scheurer M, Bigalke M (2018) Microplastics in Swiss Floodplain Soils. Environ Sci Technol 52:3591-3598 
Schnurr R., Alboiu V, Chaudhary M, et al (2018) Reducing marine pollution from single-use plastics (SUPs): A review. Mar. Pollut. Bull

Schymanski D, Goldbeck C, Humpf H-U, Fürst P (2018) Analysis of microplastics in water by micro-Raman spectroscopy: Release of plastic particles from different packaging into mineral water. Water Res 129:154162

Seltenrich N (2015) New link in the food chain? Marine plastic pollution and seafood safety. Environ Health Perspect 123:A34

Shan J, Zhao J, Liu L, et al (2018) A novel way to rapidly monitor microplastics in soil by hyperspectral imaging technology and chemometrics. Environ Pollut 238:121-129. doi: 10.1016/j.envpol.2018.03.026

Sillanpää M, Sainio P (2017) Release of polyester and cotton fibers from textiles in machine washings. Environ Sci Pollut Res 24:19313-19321. doi: 10.1007/s11356-017-9621-1

Sivan A (2011) New perspectives in plastic biodegradation. Curr Opin Biotechnol 22:422-426

Srivastava RK, Godara S (2017) Use of polycarbonate plastic products and human health. Int J Basic Clin Pharmacol 2:12-17

Steensgaard IM, Syberg K, Rist S, et al (2017) From macro-to microplastics-Analysis of EU regulation along the life cycle of plastic bags. Environ Pollut 224:289-299

Steinmetz Z, Wollmann C, Schaefer M, et al (2016) Plastic mulching in agriculture. Trading short-term agronomic benefits for long-term soil degradation? Sci Total Environ 550:690-705

Swami V, Chamorro-Premuzic T, Snelgar R, Furnham A (2011) Personality, individual differences, and demographic antecedents of self-reported household waste management behaviours. J Environ Psychol $31: 21-26$

Su L, Cai H, Kolandhasamy P, et al (2018) Using the Asian clam as an indicator of microplastic pollution in freshwater ecosystems. Environ Pollut 234:347-355

Suaria G, Avio CG, Mineo A, et al (2016) The Mediterranean Plastic Soup: synthetic polymers in Mediterranean surface waters. Sci Rep 6:37551

Sundt P, Schulze P-E, Syversen F (2014) Sources of microplastic-pollution to the marine environment. Mepex Nor Environ Agency 
Sutton R, Mason SA, Stanek SK, et al (2016) Microplastic contamination in the San Francisco Bay, California, USA. Mar Pollut Bull 109:230-235

Talvitie J, Heinonen M (2014) Preliminary study on synthetic microfibers and particles at a municipal waste water treatment plant. Balt Mar Environ Prot Comm HELCOM 1-14

Talvitie J, Heinonen M, Pääkkönen J-P, et al (2015) Do wastewater treatment plants act as a potential point source of microplastics? Preliminary study in the coastal Gulf of Finland, Baltic Sea. Water Sci Technol 72:14951504

Talvitie J, Mikola A, Setälä O, et al (2017) How well is microlitter purified from wastewater?-A detailed study on the stepwise removal of microlitter in a tertiary level wastewater treatment plant. Water Res 109:164-172

Tanaka K, Takada H (2016) Microplastic fragments and microbeads in digestive tracts of planktivorous fish from urban coastal waters. Sci Rep 6:34351

The Council of the European Union (1999) Council directive 1999/31/EC of 26 april 1999 on the landfill of waste. Off. J. Eur. Communities L182, 1-19

Thompson RC, Olsen Y, Mitchell RP, et al (2004) Lost at sea: where is all the plastic? Science 304:838-838

Trevail AM, Gabrielsen GW, Kühn S, Van Franeker JA (2015) Elevated levels of ingested plastic in a high Arctic seabird, the northern fulmar (Fulmarus glacialis). Polar Biol 38:975-981

UNEP (2014) Plastic debris in the ocean. UNEP Year Book 2014 Emerging issues update

UNEP (2018) SINGLE-USE PLASTICS: A Roadmap for $\begin{array}{lllll}\text { Sustainability. } & 104 & \text { p. }\end{array}$ https://wedocs.unep.org/bitstream/handle/20.500.11822/25496/singleUsePlastic_sustainability.pdf

United Kingdom Department for Environment Food and Rural Affairs (2016) Microbead Ban Announced to Protect Sealife. Department for Environment, Food and Rural Affairs. https://www.gov.uk/government/news/ microbead-ban-announced-to-protect-sealife

United States Congress (2015) H.R.1321 - Microbead-Free Waters Act of 2015

USEPA (2007) Phthalates. TEACH Chemical Summary.Washington, DC: Environmental Protection Agency.

Van Cauwenberghe L, Vanreusel A, Mees J, Janssen CR (2013) Microplastic pollution in deep-sea sediments. Environ Pollut 182:495-499

Van Franeker JA, Blaize C, Danielsen J, et al (2011) Monitoring plastic ingestion by the northern fulmar Fulmarus glacialis in the North Sea. Environ Pollut 159:2609-2615 
Vaughan S (2015) EU chemicals regulation: New governance, hybridity and REACH. Edward Elgar Publishing.

Vethaak AD, Leslie HA (2016) Plastic debris is a human health issue. Environ. Sci. Technol. 50: 6825-6826

Walker TR, Grant J, Archambault M-C (2006) Accumulation of marine debris on an intertidal beach in an urban park (Halifax Harbour, Nova Scotia). Water Qual Res J 41:256-262

Walker TR, Reid K, Arnould JP, Croxall JP (1997) Marine debris surveys at Bird Island, South Georgia 1990-1995. Mar Pollut Bull 34:61-65

Walker TR, Xanthos D (2018) A call for Canada to move toward zero plastic waste by reducing and recycling single-use plastics. Resour Conserv Recycl 133:99-100

Walker TR, Young SD, Crittenden PD, Zhang H (2003) Anthropogenic metal enrichment of snow and soil in northeastern European Russia. Environ Pollut 121:11-21

Waller CL, Griffiths HJ, Waluda CM, et al (2017) Microplastics in the Antarctic marine system: An emerging area of research. Sci Total Environ 598:220-227

Wang J, Tan Z, Peng J, et al (2016) The behaviors of microplastics in the marine environment. Mar Environ Res $113: 7-17$

Wardrop D, Bott C, Criddle C, et al (2016) Technical Review of Microbeads/Microplastics in the Chesapeake Bay. STAC: Edgewater, MD

Wright SL, Kelly FJ (2017) Plastic and human health: a micro issue? Environ Sci Technol 51:6634-6647

Wright SL, Thompson RC, Galloway TS (2013) The physical impacts of microplastics on marine organisms: a review. Environ Pollut 178:483-492

Xanthos D, Walker TR (2017) International policies to reduce plastic marine pollution from single-use plastics (plastic bags and microbeads): a review. Mar Pollut Bull 118:17-26

Yang D, Shi H, Li L, et al (2015) Microplastic pollution in table salts from China. Environ Sci Technol 49:1362213627

Zalasiewicz J, Waters CN, do Sul JAI, et al (2016) The geological cycle of plastics and their use as a stratigraphic indicator of the Anthropocene. Anthropocene 13:4-17

Zettler ER, Mincer TJ, Amaral-Zettler LA (2013) Life in the "plastisphere": microbial communities on plastic marine debris. Environ Sci Technol 47:7137-7146 
Zhang K, Su J, Xiong X, et al (2016) Microplastic pollution of lakeshore sediments from remote lakes in Tibet plateau, China. Environ Pollut 219:450-455

Zhang S, Yang X, Gertsen H, et al (2018) A simple method for the extraction and identification of light density microplastics from soil. Sci Total Environ 616-617:1056-1065

Zhao CX, Wang YQ, Wang YJ, et al (2014) Temporal and spatial distribution of PM2. 5 and PM10 pollution status and the correlation of particulate matters and meteorological factors during winter and spring in Beijing. Huan Jing Ke Xue Huanjing Kexue 35:418-427

Ziajahromi S, Neale PA, Leusch FD (2016) Wastewater treatment plant effluent as a source of microplastics: review of the fate, chemical interactions and potential risks to aquatic organisms. Water Sci Technol 74:22532269

Zitko V, Hanlon M (1991) Another source of pollution by plastics: skin cleaners with plastic scrubbers. Mar Pollut Bull 22:41-42

Zubris KAV, Richards BK (2005) Synthetic fibers as an indicator of land application of sludge. Environ Pollut $138: 201-211$

Zylstra ER (2013) Accumulation of wind-dispersed trash in desert environments. J Arid Environ 89:13-15 


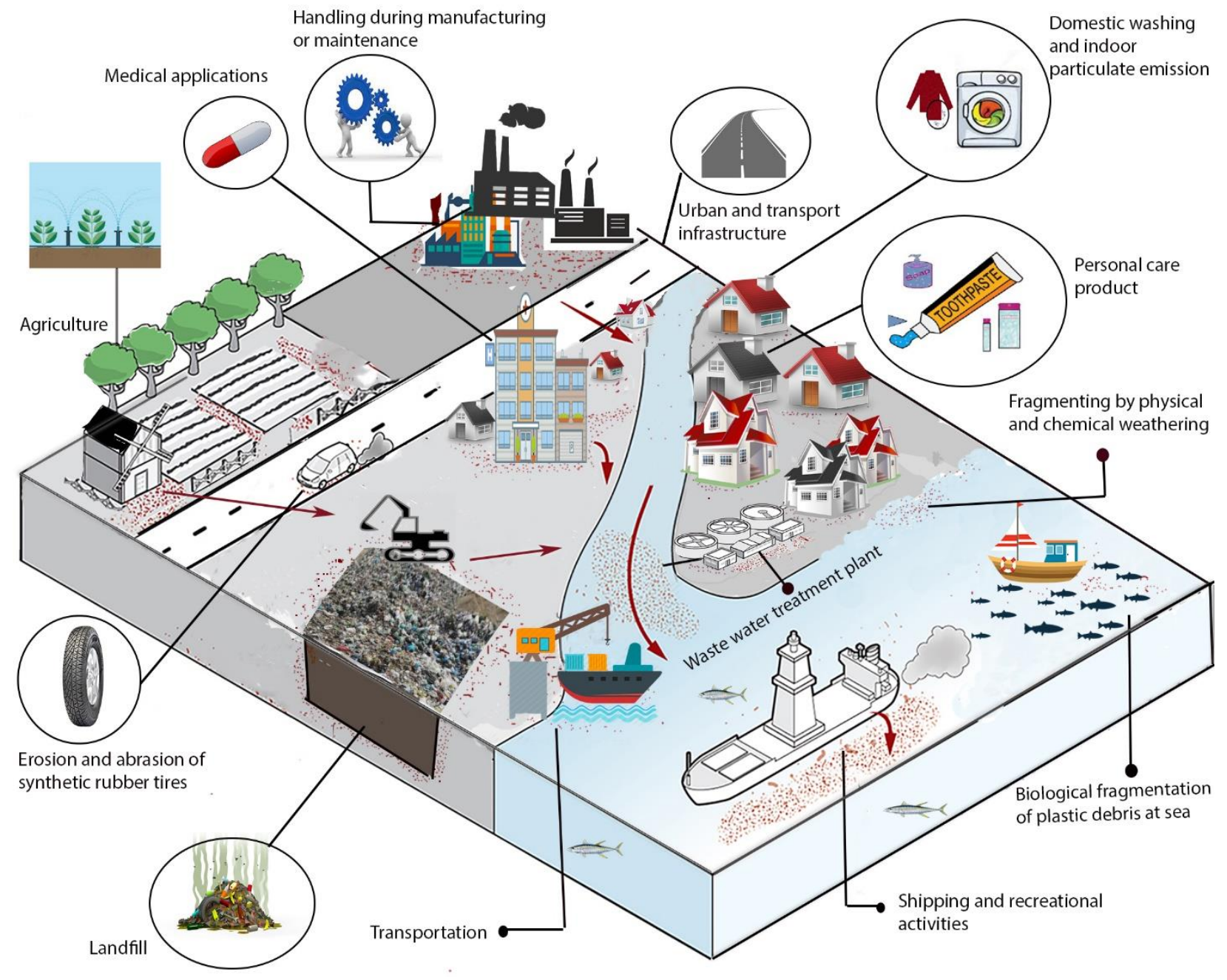

Fig 1. How microplastics contaminate the Earth's ecosystems 


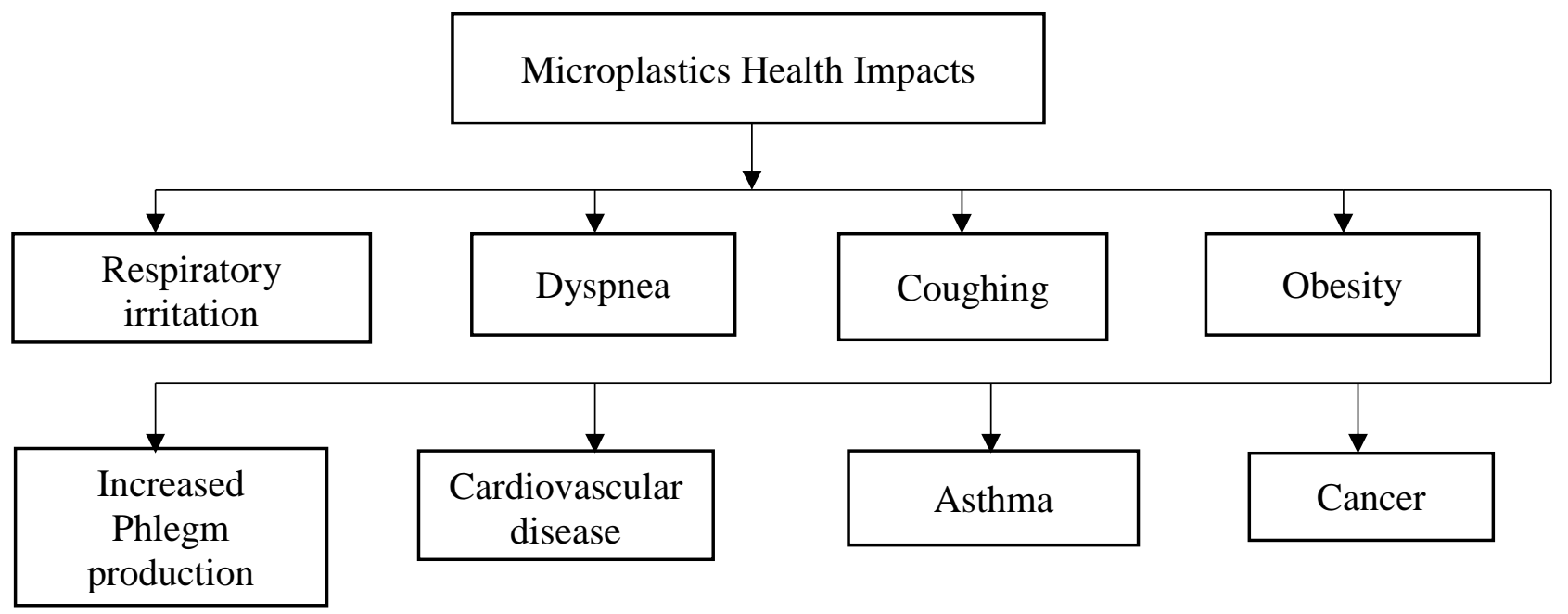

Fig 2. Summary of potential human health impacts of microplastics exposure. 
Table 1. Studies that have detected microplastics in products consumed by humans.

\begin{tabular}{|c|c|c|c|}
\hline Products & Concentration & Plastic polymer & References \\
\hline $\begin{array}{l}\text { Yellowfin bream (Acanthopagrus } \\
\text { australis) } \\
\text { Sea mullet (Mugil cephalus) } \\
\text { Silverbiddy (Gerres subfasciatus) }\end{array}$ & $\begin{array}{l}\text { mean 0.6 MPs per fish } \\
\text { mean 2.5 MPs per fish } \\
\text { mean 0.1 MPs per fish }\end{array}$ & PET, PP & (Halstead et al. 201 \\
\hline Drinking water & 50 (52) particles/L & PET, PP, PE & (Schymanski et al. 2 \\
\hline Canned sardines & $\begin{array}{l}1 \text { and } 3 \text { plastic particles } \\
\text { per brand }\end{array}$ & PP, PET, PVC, PE & (Karami et al. 2018) \\
\hline Commercial fish species & 0-3 MPs per species & PP, PE, PS, PVC & (Baalkhuyur et al. 2 \\
\hline $\begin{array}{l}\text { European sardine (Sardina } \\
\text { pilchardus) } \\
\text { European anchovy (Engraulis } \\
\text { encrasicolus) }\end{array}$ & 0 to 3 items per fish & PET, PA, polyacrylamide & (Compa et al. 2018) \\
\hline Mussels (Mytilus edulis) & $3.0(0.9) / \mathrm{g}$ & PET, PUR, Polyether & (Catarino et al. $201 \xi$ \\
\hline Oysters (Saccostrea cucullate) & $\begin{array}{l}1.4 \text { to } 7.0 \text { items per } \\
\text { individual }\end{array}$ & PET, PP, PS, PA, PVC & (Li et al. 2018) \\
\hline $\begin{array}{l}\text { Sea bass (Dicentrarchus labrax) } \\
\text { Seabream (Diplodus vulgaris) } \\
\text { Flounder (Platichthys flesus) }\end{array}$ & $\begin{array}{l}0.30(0.61) \text { MPs per fish } \\
3.14(3.25) \text { MPs per fish } \\
0.18(0.55) \text { MPs per fish }\end{array}$ & $\begin{array}{l}\text { PES, PP, Polyacrylonitrile, PE, } \\
\text { PA, nylon }\end{array}$ & (Bessa et al. 2018b) \\
\hline Sea salts & 50-280 MPs/kg & PET, PUR, PP, PE, PMMA, PA, PVC & (Iñiguez et al. 2017) \\
\hline Honey & $1760 / \mathrm{kg}$ and $8680 / \mathrm{kg}$ & PET & (Mühlschlegel et al. \\
\hline $\begin{array}{l}\text { Flounder (Platichthys flesus) and } \\
\text { European smelt (Osmerus eperlanus) }\end{array}$ & $\begin{array}{l}75 \% \text { European flounder } \\
\text { and } 20 \% \text { smelt }\end{array}$ & PA, Acrylic, Nylon, PE, and PET & (McGoran et al. 201 \\
\hline Dried fish & 61 particles & PP, PE, PS, PET, Nylon & (Karami et al. 2017t \\
\hline Sea salt & 72 particles & $\begin{array}{l}\text { PP, PE, PET, Nylon6, PS, } \\
\text { Polyacrylonitrile }\end{array}$ & (Karami et al. 2017a \\
\hline $\begin{array}{l}\text { Demersal (cod, dab, } \\
\text { flounder/pelagic fish } \\
\text { (herring and mackerel) }\end{array}$ & 54 particles $\mathrm{mg}^{-1}$ & PE, PA, PP, PS, PET, PES, PUR & (Rummel et al. 201C \\
\hline $\begin{array}{l}\text { Nile perch (Lates niloticus) and Nile } \\
\text { tilapia (Oreochromis niloticus) }\end{array}$ & $20 \%$ of each fish species & PE, PES, PP, PU & (Biginagwa et al. 20 \\
\hline $\begin{array}{l}\text { Japanese anchovy (Engraulis } \\
\text { japonicus) }\end{array}$ & $\begin{array}{l}\text { mean } 2.3 \text { MPs per } \\
\text { individual }\end{array}$ & PE, PP, PS & (Tanaka and Takada \\
\hline Atlantic cod (Gadus morhua) & $18.8 \% \mathrm{MPs}$ & PES, PP, PVC, PS, Nylon, PE & (Bråte et al. 2016) \\
\hline $\begin{array}{l}\text { Table salts } \\
\text { Lake salts } \\
\text { Rock salts }\end{array}$ & $\begin{array}{l}550-681 \text { particles } / \mathrm{kg} \\
43-364 \text { particles } / \mathrm{kg} \\
7-204 \text { particles } / \mathrm{kg}\end{array}$ & PET, PE, cellophane & (Yang et al. 2015) \\
\hline Commercial fish & $\begin{array}{l}19.8 \% \text { of fish from } 26 \\
\text { species }\end{array}$ & $\begin{array}{l}\text { PP, PE, Alkyd resin, Rayon, PES, Nylon } \\
\text { and Acrylic }\end{array}$ & (Neves et al. 2015) \\
\hline Marine fish & $2.6 \%$ of fish & PE, PP, PET, SA & (Foekema et al. 201 \\
\hline Marine fish & 1.90 (0.10) particles/fish & PS, PES, PA, Rayon & (Lusher et al. 2013) \\
\hline
\end{tabular}


Marine fish

Catfish species

(Cathorops spixii)

(Cathorops agassizii)

(Sciades herzbergii)
$7.9 \%$ of the fish

$18 \%$ of individual fish

$18 \%$ of individual fish

$33 \%$ of individual fish
PA

PA
(Dantas et al. 2012)

(Possatto et al. 2011

PET: Polyethylene-terephthalate; PP: Polypropylene; PE: Polyethylene; PS: Polystyrene; PES:

polyester; PUR: Polyurethane; PVC: Polyvinyl chloride PA: Polyamide; PMMA: Polymethylmethacrylate; SA: Styreneacrylate 